\title{
Methyl halides in surface seawater and marine boundary layer of the northwest Pacific
}

\author{
Atsushi Ooki, ${ }^{1}$ Atsushi Tsuda, ${ }^{2}$ Sohiko Kameyama, ${ }^{1,3}$ Shigenobu Takeda, ${ }^{4,5}$ \\ Sachihiko Itoh, ${ }^{2}$ Toshio Suga ${ }^{6,7}$ Hirofumi Tazoe, ${ }^{8}$ Ayako Okubo, ${ }^{2,9}$ and Yoko Yokouchi ${ }^{1}$ \\ Received 7 August 2009; revised 6 April 2010; accepted 10 June 2010; published 8 October 2010.
}

[1] The partial pressures of methyl halides $\left(\mathrm{CH}_{3} \mathrm{X} ; \mathrm{X}=\mathrm{Cl}, \mathrm{Br}\right.$, or I) and of $\mathrm{CHClF}_{2}$ (HCFC-22), which are all volatile organic compounds (VOCs), were measured in the air of the marine boundary layer $\left(p \mathrm{VOC}_{\mathrm{air}}\right)$ and in surface seawater $\left(p \mathrm{VOC}_{\mathrm{water}}\right)$ during a cruise from the subarctic to subtropical regions of the northwest Pacific in summer of 2008. In the northern transition water $\left(\mathrm{TW}_{\mathrm{N}}\right)$ with high biological activity, high levels of the three $\mathrm{CH}_{3} \mathrm{Xs}$ in surface seawater were frequently observed, probably owing to their enhanced production by phytoplankton. Supersaturation of $\mathrm{CH}_{3} \mathrm{Br}$ was only present in $\mathrm{TW}_{\mathrm{N}}$ water, with a saturation anomaly $\left(\mathrm{SCH}_{3} \mathrm{Br}\right)$ of $0.95\left[\mathrm{SCH}_{3} \mathrm{X}=\right.$ $\left(p \mathrm{CH}_{3} \mathrm{X}_{\text {water }}-p \mathrm{CH}_{3} \mathrm{X}_{\text {air }}\right) / p \mathrm{CH}_{3} \mathrm{X}_{\text {air }}$. The highest saturation anomalies for $\mathrm{CH}_{3} \mathrm{Cl}$ $\left(\mathrm{SCH}_{3} \mathrm{Cl}=1.6\right)$ and $\mathrm{CH}_{3} \mathrm{I}\left(\mathrm{SCH}_{3} \mathrm{I}=91\right)$ were found in the southern subtropical water $\left(\mathrm{ST}_{\mathrm{S}}\right)$ with low biological production south of the subtropical front. We found that the molar concentrations of $\mathrm{CH}_{3} \mathrm{Cl}\left(\mathrm{CCH}_{3} \mathrm{Cl}\right)$ and $\mathrm{CH}_{3} \mathrm{I}\left(\mathrm{CCH}_{3} \mathrm{I}\right)$ sharply increased with increasing sea surface temperature (SST) in the subtropical waters. The maximum $\mathrm{CCH}_{3} \mathrm{Cl}\left(144 \mathrm{pmol} \mathrm{l}^{-1}\right)$ was present in $\mathrm{ST}_{\mathrm{S}}$ water at $\mathrm{SST}=30^{\circ} \mathrm{C}$ and is 1.5 times the value extrapolated from the previously reported relationship between $\mathrm{CCH}_{3} \mathrm{Cl}$ and SST. Photochemical production might have contributed to the production of $\mathrm{CH}_{3} \mathrm{Cl}$ and $\mathrm{CH}_{3} \mathrm{I}$ in $\mathrm{ST}_{\mathrm{S}}$ water.

Citation: Ooki, A., A. Tsuda, S. Kameyama, S. Takeda, S. Itoh, T. Suga, H. Tazoe, A. Okubo, and Y. Yokouchi (2010), Methyl halides in surface seawater and marine boundary layer of the northwest Pacific, J. Geophys. Res., 115, C10013, doi:10.1029/2009JC005703.

\section{Introduction}

[2] Methyl chloride $\left(\mathrm{CH}_{3} \mathrm{Cl}\right)$ and methyl bromide $\left(\mathrm{CH}_{3} \mathrm{Br}\right)$ have been regarded as the largest contributors of naturally produced halogens to the stratosphere, where they are responsible for ozone destruction [World Meteorological Organization $(W M O), 2007]$, while methyl iodide $\left(\mathrm{CH}_{3} \mathrm{I}\right)$ primarily affects ozone destruction in the troposphere [Chameides and Davis, 1980] and in the lower stratosphere [Solomon et al., 1994].

\footnotetext{
${ }^{1}$ National Institute for Environmental Studies, Ibaraki, Japan.

${ }^{2}$ Atmosphere and Ocean Research Institute, University of Tokyo, Tokyo, Japan.

${ }^{3}$ Now at Faculty of Environmental Earth Science, Hokkaido University, Hokkaido, Japan.

${ }^{4}$ Graduate School of Agricultural and Life Sciences, University of Tokyo, Tokyo, Japan.

${ }^{5}$ Also at Faculty of Fisheries, Nagasaki University, Nagasaki, Japan.

${ }^{6}$ Department of Geophysics, Graduate School of Science, Tohoku University, Miyagi, Japan.

${ }^{7}$ Also at Institute of Observational Research for Global Change, Japan Agency for Marine Earth Science and Technology, Kanagawa, Japan.

${ }^{8}$ College of Humanities and Sciences, Nihon University, Tokyo, Japan.

${ }^{9}$ Now at Graduate School of Agricultural and Life Sciences, University of Tokyo, Tokyo, Japan.
}

Copyright 2010 by the American Geophysical Union. 0148-0227/10/2009JC005703
[3] A number of studies have investigated the oceanic sources and sinks of methyl halides $\left(\mathrm{CH}_{3} \mathrm{X}\right)$. Biological sources include macroalgae [Manley and Dastoor, 1987; Manley, 1992; Giese et al., 1999], phytoplankton [Scarratt and Moore, 1996; Manley and dela Cuesta, 1997; Scarratt and Moore, 1998], and bacteria for $\mathrm{CH}_{3} \mathrm{I}$ [Amachi et al., 2001; Smythe-Wright et al., 2006]. Bacterial degradation of $\mathrm{CH}_{3} \mathrm{Cl}$ and $\mathrm{CH}_{3} \mathrm{Br}$ is reportedly an important oceanic sink for these molecules [Tokarczyk et al., 2003a, 2003b]. Abiotic processes involving methyl halides include nucleophilic substitution of $\mathrm{CH}_{3} \mathrm{Br}$ and $\mathrm{CH}_{3} \mathrm{I}_{\text {by } \mathrm{Cl}^{-}}$(chloride substitution), resulting in $\mathrm{CH}_{3} \mathrm{Cl}$ [Elliott and Rowland, 1993; Jones and Carpenter, 2007], as well as photochemical production of $\mathrm{CH}_{3} \mathrm{I}$ from I and methyl radicals [Moore and Zafiriou, 1994; Happell and Wallace, 1996; Yokouchi et al., 2001, 2008; Richter and Wallace, 2004; Chuck et al., 2005] and $\mathrm{CH}_{3} \mathrm{Cl}$ from colored dissolved organic compounds (CDOM) [Moore, 2008].

[4] To estimate the global oceanic distributions of methyl halides and their oceanic fluxes, several studies examined correlations between $\mathrm{CH}_{3} \mathrm{X}$ concentrations and key oceanic parameters such as sea surface temperature (SST). The relationships between SST and concentrations of $\mathrm{CH}_{3} \mathrm{Cl}$ and $\mathrm{CH}_{3} \mathrm{Br}$ were used to estimate global oceanic fluxes, by extrapolation from the global SST distribution, for $\mathrm{CH}_{3} \mathrm{Cl}$ 


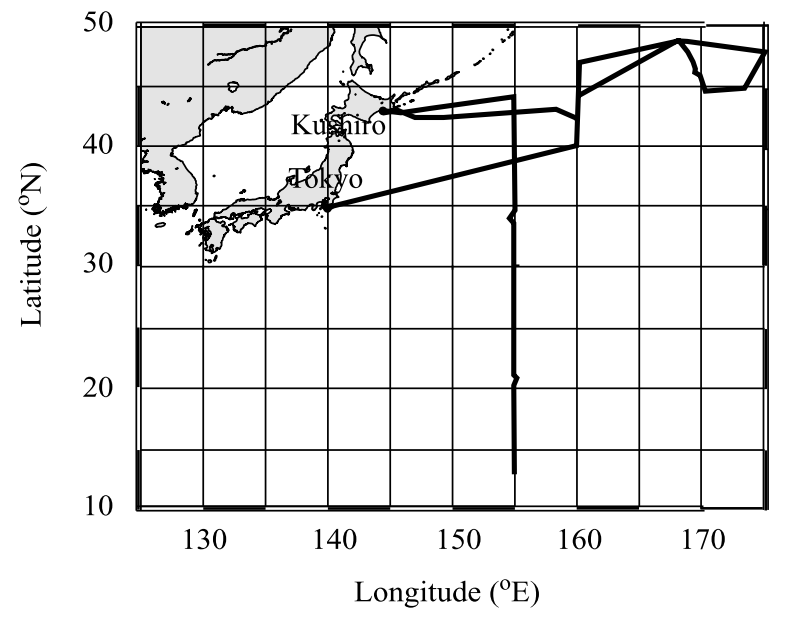

Figure 1. Track of R/V Hakuho cruise KH08-2 in 2008.

(0.3-0.7 Tg $\left.\mathrm{y}^{-1}\right)$ [Khalil et al., 1999; Moore, 2000; Yoshida et al., 2004] and for $\mathrm{CH}_{3} \mathrm{Br}\left(-10\right.$ to $\left.-21 \mathrm{Gg} \mathrm{y}^{-1}\right)$ [Lobert et al., 1995; Groszko and Moore, 1998]. Bell et al. [2002] estimated the global oceanic flux of $\mathrm{CH}_{3} \mathrm{I}\left(0.2 \mathrm{Tg} \mathrm{y}^{-1}\right)$ by integrating the photochemical production of $\mathrm{CH}_{3} \mathrm{I}$ as a function of solar radiation and dissolved organic carbon concentration. Butler et al. [2007] reported the average $\mathrm{CH}_{3} \mathrm{I}$ flux in major oceanic waters, tropical, subtropical, temperate, polar, subpolar, and coastal, and extrapolated the results to obtain the global oceanic flux of $0.6 \mathrm{Tg} \mathrm{y}^{-1}$. On the basis of these flux estimates, the ocean is considered to be the second largest source of $\mathrm{CH}_{3} \mathrm{Cl}$, and the second largest net sink of $\mathrm{CH}_{3} \mathrm{Br}$, and a major source of $\mathrm{CH}_{3} \mathrm{I}$. It is expected that the fluxes, such as the ones given above, will be altered by climate change influences on the air-sea flux of $\mathrm{CH}_{3} \mathrm{X}$ caused by a rise in SST and other changes in marine ecosystems [Anbar et al., 1996; Smythe-Wright et al., 2006; Butler et al., 2007]. For quantitative predictions of changes in $\mathrm{CH}_{3} \mathrm{X}$ flux, it is therefore essential to understand the mechanisms of production and loss of $\mathrm{CH}_{3} \mathrm{X}$ in seawater.

[5] For understanding the $\mathrm{CH}_{3} \mathrm{X}$ variability in surface seawater associated with mesoscale water mass structure, $\mathrm{CH}_{3} \mathrm{X}$ concentrations need to be determined with high frequency at a measurement cycle of several hours intervals on a ship which corresponds to several tens kilometers intervals. Recently, high-frequency measurements of $\mathrm{CH}_{3} \mathrm{I}$ and brominated halocarbons have been carried out in surface seawater and air in the Atlantic and East Pacific by means of a liquid-gas equilibrator and gas chromatograph-mass spectrometer (GC-MS) system [Butler et al., 2007]. However, there have been no high-frequency measurement studies of the $3 \mathrm{CH}_{3} \mathrm{Xs}$ in the NW Pacific, including the subarctic water and mixed water (subarctic-subtropical transition zone) with well-known high primary production, and the oligotrophic subtropical region, which has the warmest SST, of up to $30^{\circ} \mathrm{C}$ in summer. To characterize the oceanic distributions of $\mathrm{CH}_{3} \mathrm{Xs}$ in the NW Pacific, we measured $3 \mathrm{CH}_{3} \mathrm{Xs}\left(\mathrm{CH}_{3} \mathrm{Cl}\right.$, $\mathrm{CH}_{3} \mathrm{Br}$ and $\mathrm{CH}_{3} \mathrm{I}$ ) and HCFC-22 in surface seawater and in the marine boundary layer (MBL) of the NW Pacific from subarctic to subtropical regions by means of a liquid-gas equilibrator and GC-MS system as a part of the Japanese
Surface Ocean Lower Atmosphere Study (J-SOLAS). HCFC-22 is long-lived in air with lifetime of 12.0 years $[W M O, 2007]$ and is derived from terrestrial anthropogenic sources. Because it is mainly affected by physical processes such as air-sea exchange, temperature-dependent solubility and mixing, it was investigated as an indicator of the behavior of a dissolved gas that is not affected by chemical or biological processes.

\section{Methods}

\subsection{VOC Measurements}

[6] VOC measurements were conducted aboard the R/V Hakuho-maru (cruise KH08-2) in 2008 from 29 July to 19 August (Leg 1) and from 23 August to 15 September (Leg 2) in the NW Pacific (Figure 1). Surface seawater was pumped from a seawater intake on the bottom of the ship (5 m depth), and supplied to the laboratory, passing through a seawater pipe with the inner wall coated with nylon for most of its length. The surface seawater was continuously supplied to a silicone membrane tube equilibrator at a flow rate of $15 \mathrm{~L} \mathrm{~min}^{-1}$. Details of $\mathrm{CH}_{3} \mathrm{X}$ measurements are described elsewhere [Ooki and Yokouchi, 2008]. Briefly, the equilibrator consists of six silicone tubes (length, $10 \mathrm{~m}$; o.d., $2.0 \mathrm{~mm}$; i.d., $1.5 \mathrm{~mm}$ ) housed in a polyvinyl chloride (PVC) pipe. Pure air was continuously supplied to the silicone tubes at a flow rate of $25 \mathrm{~mL} \mathrm{~min}^{-1}$, regulating the inner pressure to $+0.14 \mathrm{MPa}$. The gas-phase sample of VOCs at equilibrium with the seawater could be obtained from the outlet of the silicone tube. The equilibrator was cleaned by compressed air to remove deposits after Leg 1.

[7] Outside air was drawn from the upper deck (17 $\mathrm{m}$ above the sea level) of the ship through a PTFE tube (length, $60 \mathrm{~m}$; i.d., $11 \mathrm{~mm}$ ) at a flow rate of $50 \mathrm{~L} \mathrm{~min}$. We obtained a portion of the air from the PTFE tube at a flow rate of

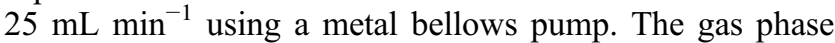
sample (equilibrated air or outside air) was dehumidified by means of Nafion ${ }^{\circledR}$ dryer and then transferred to a preconcentration/GC-MS system [Yokouchi et al., 2006]. Partial pressures of $\mathrm{CH}_{3} \mathrm{Cl}, \mathrm{CH}_{3} \mathrm{Br}, \mathrm{CH}_{3} \mathrm{I}$, and HCFC-22 in the sample of equilibrated air or outside air were measured at 70 min intervals. A gravimetrically prepared standard gas (Taiyo Nissan, Inc., Tokyo) containing these chemical species at concentrations of $100-500 \mathrm{pptv}$ was quantified according to the same procedures. The detection limits $(\mathrm{S} / \mathrm{N}=3)$ were $0.1-1$ pptv for all species. The analytical precisions of $p \mathrm{VOC}$ for all the species based on the repetitive analyses of standard gas were within $1 \%$. Overall precisions for the seawater samples were also evaluated on the basis of the observation results at the fixed sampling location $\left(\mathrm{N} 20^{\circ}, \mathrm{E} 155^{\circ}\right)$ for the duration of 2 days during the cruise. The overall precisions of $p \mathrm{VOC}_{\text {water }}(\mathrm{n}=38)$ were $3.6 \%$ for $\mathrm{CH}_{3} \mathrm{Cl}, 6.9 \%$ for $\mathrm{CH}_{3} \mathrm{Br}$, $2.9 \%$ for $\mathrm{CH}_{3} \mathrm{I}$, and $1.3 \%$ for $\mathrm{HCFC}-22$. To be noted that these overall precisions suffer from their natural variability in addition to the measurement errors.

\subsection{Sampling Line Artifact Test}

[8] To test for possible contamination or loss of $\mathrm{CH}_{3} \mathrm{X}$ in the ship's seawater sampling line, we also used a separate, brand-new sampling line including seawater intake, pump, pipe and equilibrator to collect surface seawater in parallel 


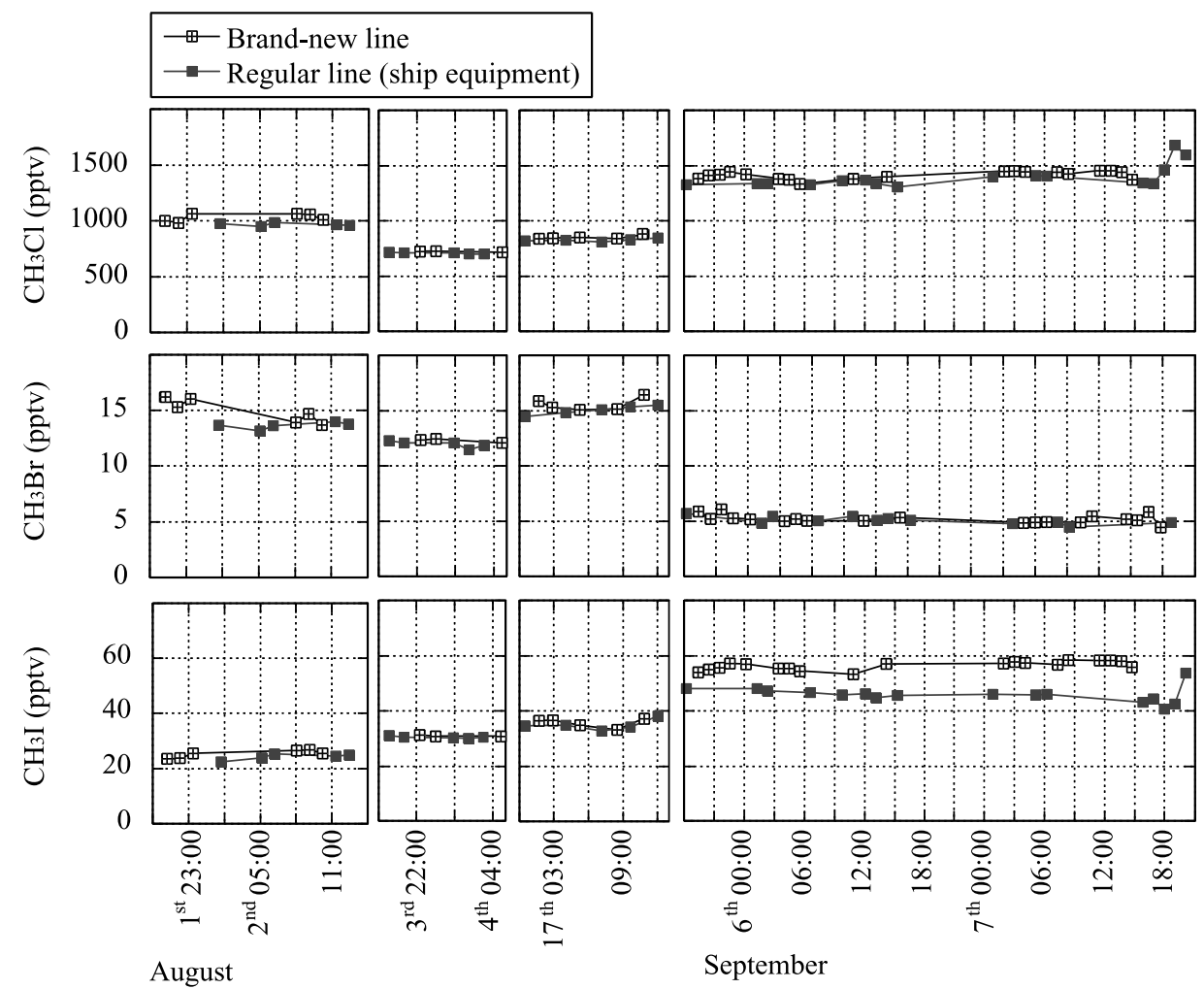

Figure 2. Seawater sampling line artifact test.

with the ship's regular sampling system. The surface seawater was drawn in by a stainless-steel screw pump through a fluororesin tube (length, $10 \mathrm{~m}$; i.d., $12 \mathrm{~mm}$ ), and transferred to the brand-new equilibrator through a Tygon ${ }^{\circledR}$ tube (length, $20 \mathrm{~m}$; i.d., $13 \mathrm{~mm}$ ). VOCs would permeate through the Tygon tube to some extent. To minimize the influence of VOCs permeation, surface seawater flowed over $3 \mathrm{~h}$ before the sampling line artifact test. The residence time of seawater in the Tygon tube was about $15 \mathrm{~s}$. We considered that contaminations and losses of $\mathrm{CH}_{3} \mathrm{X}$ in the brand-new sampling line are negligible. Comparisons were done at 4 different times, 3 times during leg 1 and once during leg 2 .

\subsection{Chlorophyll-a Measurement}

[9] Some of the environmental parameters (salinity, temperature, and chlorophyll-a) were continuously monitored with an AMEMBO II, which was a modified version of the AMEMBO system [Tsuda et al., 1993]. The system consisted of a bubble trap, thermosalinograph (SeaBird SBE21) and in vivo chlorophyll fluorometer (Wetlab). Seawater was pumped up to the system from the bottom of the ship. The chlorophyll-a concentrations determined by the AMEMBO II were calibrated against those of 107 extracted chlorophyll-a from filter samples, which were measured on board using a Turner Designs fluorometer [Welschmeyer, 1994].

\section{Results}

\subsection{Sampling Line Artifact}

[10] We found that for $\mathrm{CH}_{3} \mathrm{Cl}$ and $\mathrm{CH}_{3} \mathrm{Br}$, there were no significant differences in their partial pressures when the sampling lines were switched (Figure 2). This result suggests that contamination and loss of these compounds in the sampling lines were negligible. As for $\mathrm{CH}_{3} \mathrm{I}$, the partial pressure was consistently lower by about $12 \%$ when the sampling line was switched from the "brand new" line to the "regular" line during the second leg. This indicates that about $12 \%$ of $\mathrm{CH}_{3} \mathrm{I}$ in seawater was lost in the regular line during the second leg. This methyl iodide might have been lost through interaction with the iron mold-like deposits that were found on the inner surface of the equilibrator. We applied a $12 \%$ correction to the measured $p \mathrm{CH}_{3} \mathrm{I}$ in the surface seawater during the second leg under the assumption that the constant rate $(12 \%)$ of the $\mathrm{CH}_{3} \mathrm{I}$ had been lost.

\subsection{Water Type and Chlorophyll-a Concentration}

[11] The frontal structure in the subarctic-subtropical transition area in NW Pacific is characterized by the cold Oyashio current and the warm Kuroshio current [Yasuda, 2003]. From the conductivity-temperature-depth (CTD) profiles obtained at intervals of $1^{\circ}$ along $155^{\circ} \mathrm{E}$ from $44^{\circ} \mathrm{N}$ to $12^{\circ} \mathrm{N}$, we identified the subarctic front, the subarctic boundary, the Kuroshio extension front, and the subtropical front at around $44^{\circ} \mathrm{N}, 40^{\circ} \mathrm{N}, 32^{\circ} \mathrm{N}$, and $25^{\circ} \mathrm{N}$, respectively (Figure 3). Latitudinal distributions of SST and chlorophylla concentration in surface seawater are shown in Figure 3. We classified the surface seawater into five water types: (1) subarctic water (SA) to the north of the subarctic front in $44-49^{\circ} \mathrm{N}$ (approximately $\mathrm{SST}=11-16^{\circ} \mathrm{C}$ ); (2) northern transition water $\left(\mathrm{TW}_{\mathrm{N}}\right)$ between the subarctic front and the subarctic boundary in $40-44^{\circ} \mathrm{N}$ (approximately SST = 


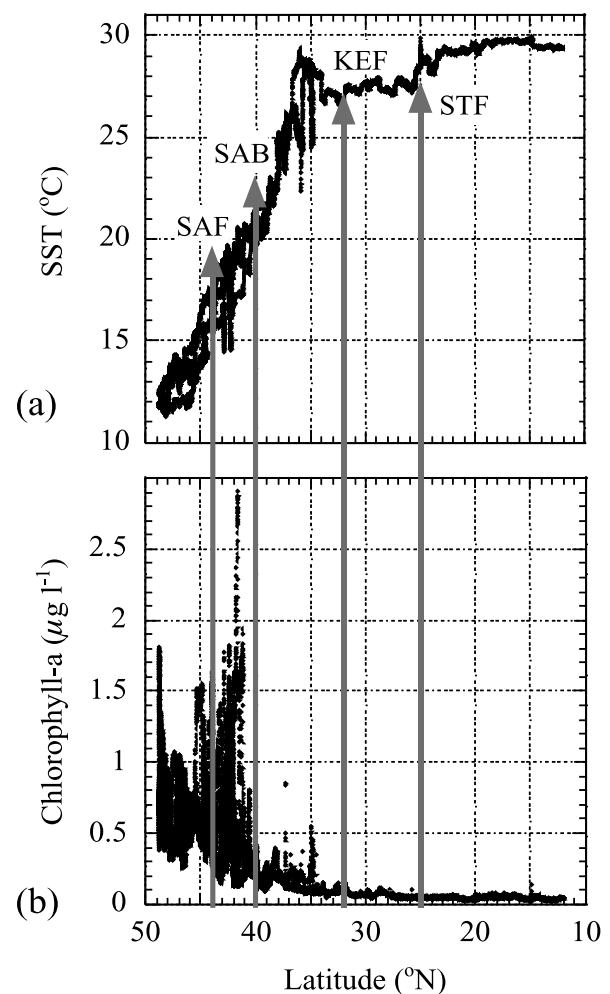

Figure 3. Latitudinal distributions of (a) SST and (b) chlorophyll-a concentration in surface seawater. Grey arrows show the locations of subarctic front (SAF), subarctic boundary (SAB), Kuroshio extension front (KEF), and subtropical front (STF).

$\left.16-20^{\circ} \mathrm{C}\right)$; (3) southern transition water $\left(\mathrm{TW}_{\mathrm{S}}\right)$ between the subarctic boundary and the Kuroshio extension front in $32-40^{\circ} \mathrm{N}$ (approximately $\mathrm{SST}=20-27^{\circ} \mathrm{C}$ ); (4) northern subtropical water $\left(\mathrm{ST}_{\mathrm{N}}\right)$ between the Kuroshio extension front and the subtropical front in $32-25^{\circ} \mathrm{N}$ (approximately with SST $=27-28^{\circ} \mathrm{C}$ ); and (5) southern subtropical water $\left(\mathrm{ST}_{\mathrm{S}}\right)$ to the south of the subtropical front in $25-12^{\circ} \mathrm{N}$ (approximately $\mathrm{SST}=28-30^{\circ} \mathrm{C}$ ). Warm water with $\mathrm{SST}=$ $28-29^{\circ} \mathrm{C}$ was found around $35^{\circ} \mathrm{N} 155^{\circ} \mathrm{E}$ within the $\mathrm{TW}_{\mathrm{S}}$ water that came from the Kuroshio current.

[12] We found high concentrations of chlorophyll-a in SA surface seawater (average, $0.68 \mu \mathrm{g} \mathrm{l}^{-1}$ ) and in $\mathrm{TW}_{\mathrm{N}}$ water (average $0.56 \mu \mathrm{g} \mathrm{l}^{-1}$ ). The average chlorophyll-a concentrations of $\mathrm{TW}_{\mathrm{S}}, \mathrm{ST}_{\mathrm{N}}$, and $\mathrm{ST}_{\mathrm{S}}$ were $0.15 \mu \mathrm{g} \mathrm{l}^{-1}, 0.07 \mu \mathrm{g} \mathrm{l}^{-1}$, and $0.05 \mu \mathrm{g} \mathrm{l}^{-1}$, respectively. The biological production in the oligotrophic $\mathrm{ST}_{\mathrm{N}}$ and $\mathrm{ST}_{\mathrm{S}}$ waters was low compared to the waters of the other regions.

\subsection{Latitudinal Distributions of $\mathrm{pCH}_{3} \mathrm{X}$ and pHCFC-22 in Surface Seawater and the Marine Boundary Layer}

[13] Latitudinal distributions of $p \mathrm{VOC}_{\mathrm{water}}$ and $p \mathrm{VOC}_{\mathrm{air}}$ are shown in Figure 4 . The variation of $p \mathrm{CH}_{3} \mathrm{X}_{\text {air }}$ during the cruise was much less than that of $p \mathrm{CH}_{3} \mathrm{X}_{\text {water. The satura- }}$ tion anomaly of a VOC $\left(\mathrm{S}_{\mathrm{VOC}}\right)$ is defined as:

$$
\mathrm{S}_{\mathrm{VOC}}=\left(p \mathrm{VOC}_{\mathrm{water}}-p \mathrm{VOC}_{\mathrm{air}}\right) / p \mathrm{VOC}_{\mathrm{air}} \text {, }
$$

where $p \mathrm{VOC}_{\mathrm{water}}$ is the partial pressure in water and $p \mathrm{VOC}_{\text {air }}$ in air. Values for $p \mathrm{VOC}$ and $\mathrm{S}_{\mathrm{VOC}}$ are summarized in Tables 1 and 2, respectively.

\subsubsection{HCFC-22}

[14] The average $p$ HCFC-22 air of 203 pptv $(1 \sigma=9.0, \mathrm{n}=$ 99) during the cruise was consistent with the summertime average (204 pptv) in 2008 at Cape Ochiishi $\left(43^{\circ} \mathrm{N}, 145^{\circ} \mathrm{E}\right)$ in the northern part of Japan [Yokouchi et al., 2009]. The $p$ HCFC-22 2 water in $\mathrm{SA}, \mathrm{TW}_{\mathrm{N}}, \mathrm{TW}_{\mathrm{S}}$, and $\mathrm{ST}_{\mathrm{N}}$ waters were slightly higher than the average $p \mathrm{HCFC}-22_{\text {air }}$ of all the samples, whereas $p \mathrm{HCFC}-22_{\text {water }}$ in $\mathrm{ST}_{\mathrm{S}}$ water was slightly below the average of $p \mathrm{HCFC}-22_{\text {air. }}$ We found higher SHCFC-22 in the colder waters, ranging from -0.02 to 0.10 (Table 2). SST increased in SA water $\left(+4^{\circ} \mathrm{C}\right.$ month $\left.{ }^{-1}\right)$ at $45^{\circ} \mathrm{N}, 155^{\circ} \mathrm{E}$ from July to August 2008 and at a faster rate than in $\mathrm{ST}_{\mathrm{S}}$ water $\left(+0.5^{\circ} \mathrm{C}\right.$ month $\left.{ }^{-1}\right)$ at $25^{\circ} \mathrm{N}, 155^{\circ} \mathrm{E}$ according to Japan Meteorological Agency (http://www. jma.go.jp/jma/index.html). The relatively high SHCFC-22 in SA water could be explained by the rapid decrease of solubility as a result of the rise in SST.

\subsection{2. $\mathrm{CH}_{3} \mathrm{Cl}$}

[15] The average $p \mathrm{CH}_{3} \mathrm{Cl}_{\text {air }}$ of 583 pptv $(1 \sigma=47, \mathrm{n}=110)$ during the cruise was higher than the annual global average of 550 pptv [WMO, 2007]. On the whole, $p \mathrm{CH}_{3} \mathrm{Cl}_{\text {water }}$ increased toward the south. For most of the SA water, $p \mathrm{CH}_{3} \mathrm{Cl}_{\text {water was }}$ less than $p \mathrm{CH}_{3} \mathrm{Cl}_{\text {air }}$, with an average $\mathrm{SCH}_{3} \mathrm{Cl}$ of -0.07 . In $\mathrm{TW}_{\mathrm{N}}$ water, high levels of $p \mathrm{CH}_{3} \mathrm{Cl}_{\text {water }}$ (up to 1313 pptv) were frequently observed. In $\mathrm{TW}_{\mathrm{S}}$ water, there were high levels of $p \mathrm{CH}_{3} \mathrm{Cl}_{\text {water }}$ (up to $1645 \mathrm{pptv}$ ) around $35^{\circ} \mathrm{N} 155^{\circ} \mathrm{E}$ in the warm Kuroshio water. In $\mathrm{ST}_{\mathrm{S}}$ water, the $p \mathrm{CH}_{3} \mathrm{Cl}_{\text {water }}$ maximum was present between $15^{\circ} \mathrm{N}$ and $20^{\circ} \mathrm{N}$, where a SST maximum of up to $30^{\circ} \mathrm{C}$ could be seen (Figure $3 \mathrm{~b}$ ). The highest $p \mathrm{CH}_{3} \mathrm{Cl}_{\text {water }}$ in $\mathrm{ST}_{\mathrm{S}}$ (1893 pptv) was 1.6 times the previously reported highest value (1200 pptv) in the subtropical East Pacific [Moore et al., 1996]. A higher (or lower) $\mathrm{SCH}_{3} \mathrm{X}$ compared to SHCFC-22 suggests chemical or biological production (or loss) of $\mathrm{CH}_{3} \mathrm{X}$ in surface seawater, because the saturation anomaly of long-lived HCFC-22 is mainly controlled by changes of temperature-dependent solubility in seawater and air-sea exchange. The supersaturation levels of $\mathrm{CH}_{3} \mathrm{Cl}\left(\mathrm{SCH}_{3} \mathrm{Cl}=0.48-1.6\right)$, which were higher than those of HCFC-22 (SHCFC-22 $=-0.02$ to 0.08 ) in $\mathrm{TW}_{\mathrm{N}}, \mathrm{TW}_{\mathrm{S}}, \mathrm{ST}_{\mathrm{N}}$, and $\mathrm{ST}_{\mathrm{S}}$ waters, indicates net production of $\mathrm{CH}_{3} \mathrm{Cl}$ in these waters. Similar levels of supersaturation $\left(\mathrm{SCH}_{3} \mathrm{Cl}=0.38\right)$ in surface seawater warmer than $12^{\circ} \mathrm{C}$ around $40^{\circ} \mathrm{N}$ in the northwest Atlantic in summer were attributed to net production of $\mathrm{CH}_{3} \mathrm{Cl}$ [MacDonald and Moore, 2007]. In contrast, the slight undersaturation $\left(\mathrm{SCH}_{3} \mathrm{Cl}=-0.07\right)$ in $\mathrm{SA}$ water suggests net loss of $\mathrm{CH}_{3} \mathrm{Cl}$ in the surface seawater. Similar levels of undersaturation $\left(\mathrm{SCH}_{3} \mathrm{Cl}=-0.03\right.$ to -0.15$)$ have been found in the North Atlantic around $45-50^{\circ} \mathrm{N}$ in summer [MacDonald and Moore, 2007] and were attributed to bacterial degradation [Tokarczyk et al., 2003a, 2003b].

\subsection{3. $\mathrm{CH}_{3} \mathrm{Br}$}

[16] The average $p \mathrm{CH}_{3} \mathrm{Br}_{\text {air }}$ of 8.2 pptv $(1 \sigma=1.1, \mathrm{n}=$ 110) during the cruise was consistent with the northern hemispheric average of 7.7 pptv in summer of 2008 [Yvon-Lewis et al., 2009]. As with $\mathrm{CH}_{3} \mathrm{Cl}$, in SA water most $p \mathrm{CH}_{3} \mathrm{Br}_{\text {water }}$ values were less than $p \mathrm{CH}_{3} \mathrm{Br}_{\text {air }}$, with $\mathrm{SCH}_{3} \mathrm{Br}=-0.12$, and in $\mathrm{TW}_{\mathrm{N}}$ water, high levels of $p \mathrm{CH}_{3} \mathrm{Br}_{\text {water }}$ (up to $35 \mathrm{pptv}$ ) were frequently present, with 

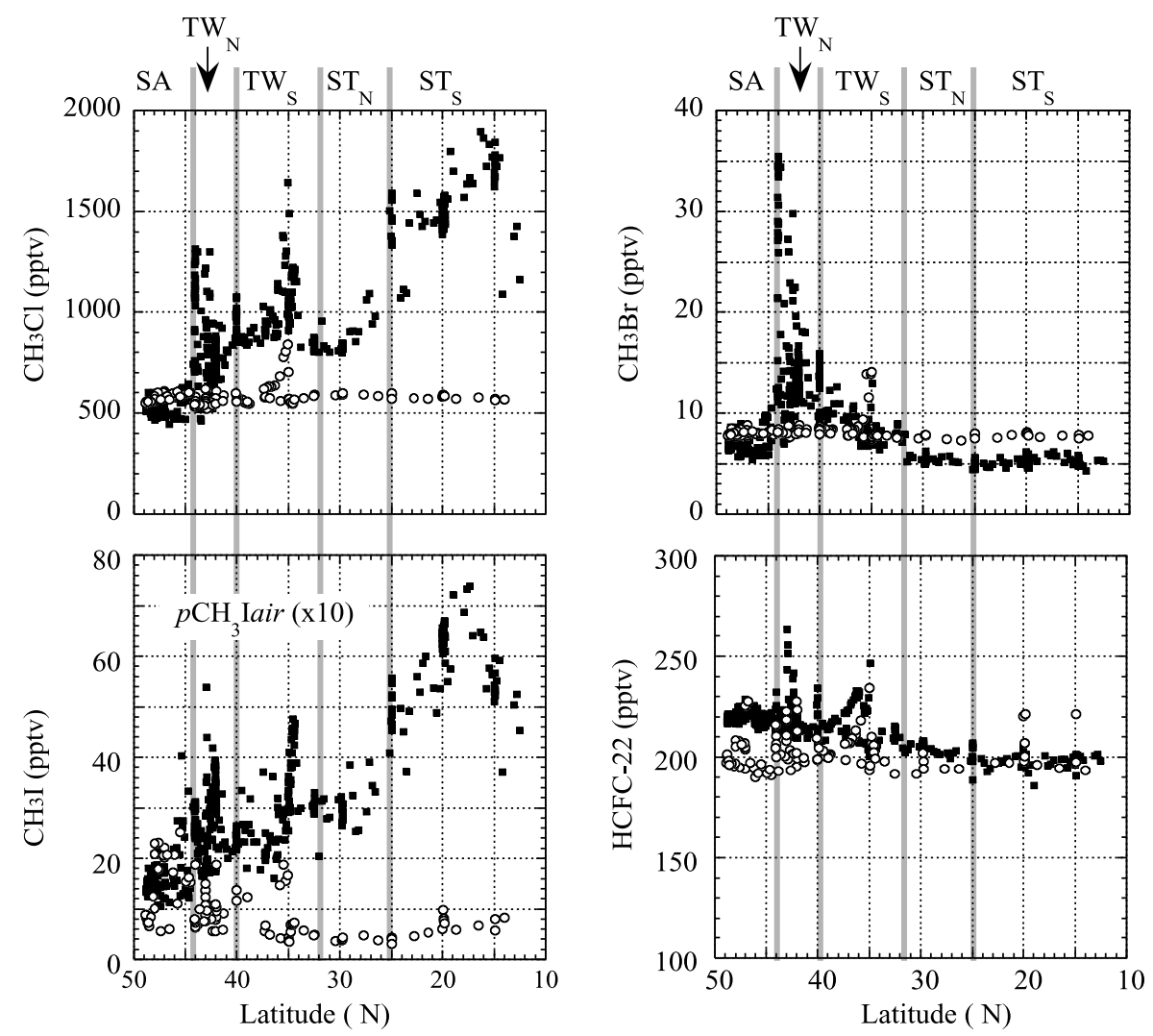

Figure 4. Latitudinal distributions of partial pressures (pptv) of $\mathrm{CH}_{3} \mathrm{X}$ and $\mathrm{HCFC}-22$ in surface seawater (squares) and the MBL (circles). SA, subarctic water; $\mathrm{ST}_{\mathrm{N}}$, northern subtropical water; and $\mathrm{ST}_{\mathrm{S}}$, southern subtropical water; $\mathrm{TW}_{\mathrm{N}}$, northern transition water; and $\mathrm{TW}_{\mathrm{S}}$, southern transition water. See section 3.2 for water mass details. The plots of $p \mathrm{CH}_{3} \mathrm{I}_{\text {air }}$ were decoupled in the figure.

$\mathrm{SCH}_{3} \mathrm{Br}=0.95$. In $\mathrm{TW}_{\mathrm{S}}$ water, $p \mathrm{CH}_{3} \mathrm{Br}_{\text {water }}$ gradually declined southward, from $10 \mathrm{pptv}$ to $8 \mathrm{pptv}$, and dropped below $p \mathrm{CH}_{3} \mathrm{Br}_{\text {air }}$ at $32^{\circ} \mathrm{N}$ near the Kuroshio extension front. In $\mathrm{ST}_{\mathrm{N}}$ and $\mathrm{ST}_{\mathrm{S}}$ waters, $p \mathrm{CH}_{3} \mathrm{Br}_{\text {water }}$ remained below $p \mathrm{CH}_{3} \mathrm{Br}_{\text {air }}$ with average $\mathrm{SCH}_{3} \mathrm{Br}$ values of -0.27 and -0.33 , respectively. The values of $\mathrm{SCH}_{3} \mathrm{Br}$ in $\mathrm{SA}$, $\mathrm{ST}_{\mathrm{N}}$ and $\mathrm{ST}_{\mathrm{S}}(-0.12,-0.27$ and -0.33$)$ were similar to those in polar and tropical waters of the Atlantic and Pacific Oceans $\left(\mathrm{SCH}_{3} \mathrm{Br}=-0.15\right.$ to -0.36$)$ from the cruises in spring/summer of 1998-1999 [King et al., 2002]. $\mathrm{SCH}_{3} \mathrm{Br}$ of 0.95 in $\mathrm{TW}_{\mathrm{N}}$ was higher than the supersaturation $\left(\mathrm{SCH}_{3} \mathrm{Br}=\right.$ $0.5-0.6)$ observed in Atlantic Ocean water $\left(41-42^{\circ} \mathrm{N}\right)$ in summer of 1998 [King et al., 2000]. Yvon-Lewis et al. [2009] estimated the change of annual saturation state of $\mathrm{CH}_{3} \mathrm{Br}$ in the global ocean, shifting from -0.12 in 1996 to -0.06 in 2007 , owing to the decline of atmospheric $\mathrm{CH}_{3} \mathrm{Br}$ level during the phaseout period since 1998. The saturation state of $\mathrm{CH}_{3} \mathrm{Br}$ in our study area would have been affected by the decline of atmospheric $\mathrm{CH}_{3} \mathrm{Br}$ level. However, we cannot analyze the interannual change of the saturation state in detail, because our measurements are limited to the NW Pacific from subarctic to subtropical in summer of 2008. More measurements covering the oceans where the saturation states of $\mathrm{CH}_{3} \mathrm{Br}$ have been measured before the phaseout should be required to evaluate the interannual change of the saturation state.

Table 1. Ranges (Averages) of $p \mathrm{VOC}_{\mathrm{air}}$ and $p \mathrm{VOC}_{\mathrm{water}}$ in Different Water Masses ${ }^{\mathrm{a}}$

\begin{tabular}{lllllll}
\hline & $\mathrm{SA}\left(44-49^{\circ} \mathrm{N}\right)$ & $\mathrm{TW}_{\mathrm{N}}\left(40-44^{\circ} \mathrm{N}\right)$ & $\mathrm{TW}_{\mathrm{S}}\left(32-40^{\circ} \mathrm{N}\right)$ & $\mathrm{ST}_{\mathrm{N}}\left(25-32^{\circ} \mathrm{N}\right)$ & $\mathrm{ST}_{\mathrm{S}}\left(12-25^{\circ} \mathrm{N}\right)$ & $\mathrm{All}^{\left(12-49^{\circ} \mathrm{N}\right)}$ \\
\hline $\mathrm{CH}_{3} \mathrm{Cl}$ Water (pptv) & $446-742(537)$ & $462-1313(841)$ & $801-1645(1007)$ & $798-1095(871)$ & $1072-1893(1530)$ & $446-1894(959)$ \\
Air (pptv) & $549-607(579)$ & $521-609(559)$ & $546-840(603)$ & $583-597(590)$ & $564-600(578)$ & $521-840(583)$ \\
$\mathrm{CH}_{3}$ Br Water (pptv) & $5.4-12(7.1)$ & $7.0-35(16)$ & $6.4-13(8.4)$ & $4.9-7.9(5.5)$ & $4.3-6.2(5.2)$ & $4.3-35(9.8)$ \\
Air (pptv) & $7.7-8.9(8.1)$ & $7.6-8.8(8.2)$ & $7.4-14(8.7)$ & $7.3-7.9(7.6)$ & $7.5-8.1(7.8)$ & $7.3-14(8.2)$ \\
$\mathrm{CH}_{3} \mathrm{I}$ Water (pptv) & $11-40(17)$ & $16-54(27)$ & $16-48(30)$ & $25-39(30)$ & $37-74(58)$ & $11-74(32)$ \\
Air (pptv) & $0.56-2.5(1.5)$ & $0.56-1.9(0.91)$ & $0.35-1.9(0.84)$ & $0.36-0.48(0.41)$ & $0.30-0.98(0.63)$ & $0.30-2.5(0.99)$ \\
HCFC-22 Water (pptv) & $214-229(220)$ & $209-263(220)$ & $200-246(212)$ & $199-208(204)$ & $186-207(199)$ & $186-263(214)$ \\
Air (pptv) & $190-228(200)$ & $193-228(204)$ & $192-234(204)$ & $192-202(196)$ & $194-221(204)$ & $190-234(203)$ \\
\hline
\end{tabular}

${ }^{\mathrm{a}} p \mathrm{VOC}_{\mathrm{water}}$ is the partial pressure in water and $p \mathrm{VOC}_{\mathrm{air}}$ in air. Abbreviations are as follows: $\mathrm{SA}$, subarctic water; $\mathrm{ST}_{\mathrm{N}}$, northern subtropical water; $\mathrm{ST}_{\mathrm{S}}$ southern subtropical water; $\mathrm{TW}_{\mathrm{N}}$, northern transition water; and $\mathrm{TW}_{\mathrm{S}}$, southern transition water. See section 3.2 for water mass details. Here pptv $=1 \times$ $10^{-12}$. Values in parentheses represent averages. 
Table 2. Averages of the Saturation Anomaly ${ }^{\mathrm{a}}$

\begin{tabular}{lcccccc}
\hline & $\mathrm{SA}\left(44-49^{\circ} \mathrm{N}\right)$ & $\mathrm{TW}_{\mathrm{N}}\left(40-44^{\circ} \mathrm{N}\right)$ & $\mathrm{TW}_{\mathrm{S}}\left(32-40^{\circ} \mathrm{N}\right)$ & $\mathrm{ST}_{\mathrm{N}}\left(25-32^{\circ} \mathrm{N}\right)$ & $\mathrm{ST}_{\mathrm{S}}\left(12-25^{\circ} \mathrm{N}\right)$ & $\mathrm{All}^{\left(12-49^{\circ} \mathrm{N}\right)}$ \\
\hline $\mathrm{CH}_{3} \mathrm{Cl}$ & -0.07 & 0.50 & 0.67 & 0.48 & 1.6 & 0.64 \\
$\mathrm{CH}_{3} \mathrm{Br}$ & -0.12 & 0.95 & -0.03 & -0.27 & -0.33 & 0.20 \\
$\mathrm{CH}_{3} \mathrm{I}$ & 10 & 29 & 35 & 72 & -0.04 & 31 \\
$\mathrm{HCFC}-22$ & 0.10 & 0.08 & 0.04 & 0.04 & -0.02 & 0.05 \\
\hline
\end{tabular}

${ }^{a}$ Abbreviations are as follows: $\mathrm{SA}$, subarctic water; $\mathrm{ST}_{\mathrm{N}}$, northern subtropical water; $\mathrm{ST}_{\mathrm{S}}$, southern subtropical water; $\mathrm{TW}_{\mathrm{N}}$, northern transition water; and $\mathrm{TW}_{\mathrm{S}}$, southern transition water. See section 3.2 for water mass details.

\subsection{4. $\mathrm{CH}_{3} \mathrm{I}$}

[17] The range of $p \mathrm{CH}_{3} \mathrm{I}_{\text {air }}$ was $0.30-2.5 \mathrm{pptv}$ (average 0.99 pptv, $1 \sigma=0.57, \mathrm{n}=95)$ during the cruise and was consistent with the previously reported values of $0.5-2 \mathrm{pptv}$ in the MBL over the NW Pacific in August-October when an annual maximum was found [Yokouchi et al., 2001]. On the whole, $p \mathrm{CH}_{3} \mathrm{I}_{\text {water }}$ increased toward the south. During the cruise, $p \mathrm{CH}_{3} \mathrm{I}_{\text {water }}$ was much higher than $p \mathrm{CH}_{3} \mathrm{I}_{\text {air }}$ with an average $\mathrm{SCH}_{3} \mathrm{I}$ of 31 , indicating net production of $\mathrm{CH}_{3} \mathrm{I}$ in the surface seawater. As with $\mathrm{CH}_{3} \mathrm{Cl}$, high levels of $p \mathrm{CH}_{3} \mathrm{I}_{\text {water }}$ were frequently observed in $\mathrm{TW}_{\mathrm{N}}$ water and in the warm Kuroshio water at $35^{\circ} \mathrm{N}, 155^{\circ} \mathrm{E}$. The $p \mathrm{CH}_{3} \mathrm{I}_{\text {water }}$ maximum was between $15^{\circ} \mathrm{N}$ and $20^{\circ} \mathrm{N}$. Previous studies have also reported higher values for $p \mathrm{CH}_{3} \mathrm{I}_{\text {water }}$ in the mixed water and the subtropical water [Schall et al., 1997; SmytheWright et al., 2006]. The average $p \mathrm{CH}_{3} \mathrm{I}_{\text {water }}$ (32 pptv) during the cruise was somewhat higher than the previously reported values for tropical water (average $25 \mathrm{pptv}$, range 11-44 pptv), central gyre water (average 21 pptv, range 6.2 49 pptv), and coastal water (average 15 pptv, range 2.9$32 \mathrm{pptv}$ ) of the Atlantic and Pacific Oceans observed during various seasons [Butler et al., 2007].

\subsection{Air-Sea Flux and Chloride Substitution}

[18] In order to discuss production and loss of $\mathrm{CH}_{3} \mathrm{Xs}$ in seawater, we estimated air-sea flux and chloride substitution of $\mathrm{CH}_{3} \mathrm{Xs}$ in the mixed layer of the ocean along the ship's track along $155^{\circ} \mathrm{E}$ from $13^{\circ} \mathrm{N}$ to $44^{\circ} \mathrm{N}$ and $160^{\circ} \mathrm{E}$ from $40^{\circ} \mathrm{N}$ to $47^{\circ} \mathrm{N}$ at $1^{\circ}$ intervals, where the CTD depth profiles were obtained. Air-sea flux of $\mathrm{CH}_{3} \mathrm{X}\left(\mathrm{FCH}_{3} \mathrm{X} ; \mathrm{nmol} \mathrm{m}{ }^{-2} \mathrm{~h}^{-1}\right)$ were calculated by:

$$
\mathrm{FCH}_{3} \mathrm{X}=-\mathrm{K} \cdot\left(p \mathrm{CH}_{3} \mathrm{X}_{\text {water }}-p \mathrm{CH}_{3} \mathrm{X}_{\text {air }}\right) \cdot \mathrm{HCH}_{3} \mathrm{X},
$$

where $\mathrm{K}$ is the gas transfer velocity $\left(\mathrm{cm} \mathrm{s}^{-1}\right)$, which depends on wind speed [Wanninkhof, 1992]. The average wind speed over the 2 weeks prior to sampling at each location was obtained from the meteorological analysis data of HYSPLIT (NOAA; http://www.ready.noaa.gov/ready/ open/hysplit4.html) and used for the air-sea flux calculation. $\mathrm{HCH}_{3} \mathrm{X}$ is the temperature-dependent Henry's law constant (mol $1^{-1} \mathrm{~atm}^{-1}$ ) obtained from Moore [2000] for $\mathrm{CH}_{3} \mathrm{Cl}$, Wilhelm et al. [1977] for $\mathrm{CH}_{3} \mathrm{Br}$, and Hunter-Smith et al. [1983] for $\mathrm{CH}_{3} \mathrm{I}$. Positive and negative values of air-sea flux mean air-to-sea influx and sea-to-air efflux, respectively.

[19] Molar concentrations (pmol $\left.1^{-1}\right)$ of $\mathrm{CH}_{3} \mathrm{X}\left(\mathrm{CCH}_{3} \mathrm{X}\right)$ in seawater were calculated by:

$$
\mathrm{CCH}_{3} \mathrm{X}=\mathrm{HCH}_{3} \mathrm{X} \cdot p \mathrm{CH}_{3} \mathrm{X}_{\text {water }} \text {. }
$$

The loss rates of $\mathrm{CH}_{3} \mathrm{Br}$ and $\mathrm{CH}_{3} \mathrm{I}$ per unit volume $\left(\mathrm{VCH}_{3} \mathrm{Br}\right.$ and $\mathrm{VCH}_{3} \mathrm{I}$; pmol $\mathrm{l}^{-1} \mathrm{~h}^{-1}$ ) via chloride substitution can be calculated by the following equations:

$$
\begin{gathered}
\mathrm{VCH}_{3} \mathrm{Br}=-\mathrm{kCH}_{3} \mathrm{Br} \cdot \mathrm{CCH}_{3} \mathrm{Br} \cdot\left[\mathrm{Cl}^{-}\right] \\
\mathrm{VCH}_{3} \mathrm{I}=-\mathrm{kCH}_{3} \mathrm{I} \cdot \mathrm{CCH}_{3} \mathrm{I} \cdot\left[\mathrm{Cl}^{-}\right],
\end{gathered}
$$

\begin{tabular}{|c|c|c|c|c|c|c|c|}
\hline & \multicolumn{5}{|c|}{ Water Type } & \multirow[b]{2}{*}{ Average } & \multirow[b]{2}{*}{ Global Average } \\
\hline & SA & $\mathrm{TW}_{\mathrm{N}}$ & $\mathrm{TW}_{\mathrm{S}}$ & $\mathrm{ST}_{\mathrm{N}}$ & $\mathrm{ST}_{\mathrm{S}}$ & & \\
\hline Mixed layer depth (m) & 15 & 18 & 17 & 21 & 38 & 25 & \\
\hline Wind speed $\left(\mathrm{m} \mathrm{s}^{-1}\right)$ & 4.1 & 5.2 & 5.7 & 6.1 & 4.4 & 5.1 & \\
\hline $\operatorname{SST}\left({ }^{\circ} \mathrm{C}\right)$ & 13.9 & 17.8 & 25.3 & 27.4 & 29.3 & 24.6 & \\
\hline \multicolumn{8}{|c|}{$\mathrm{CH}_{3} \mathrm{Cl}\left(\mathrm{nmol} \mathrm{m} \mathrm{m}^{-2} h^{-i}\right)$} \\
\hline Air-sea flux & +0.71 & -4.1 & -4.2 & -4.1 & -5.5 & -4.2 & -2.0 to $-4.1^{\mathrm{b}}$ \\
\hline $\mathrm{ACH}_{3} \mathrm{Cl}$ & +0.05 & \multicolumn{2}{|c|}{$\mathrm{CH}_{3} \mathrm{Br}\left(\mathrm{nmol} \mathrm{m}^{-2} h^{-i}\right)$} & +0.47 & +1.7 & 0.75 & \\
\hline Air-sea flux & +0.03 & -0.20 & $\begin{array}{c}H_{3} D r(n \\
-0.02\end{array}$ & +0.05 & +0.03 & -0.02 & +0.03 to $+0.07^{\mathrm{c}}$ \\
\hline $\mathrm{ACH}_{3} \mathrm{Br}$ & -0.03 & -0.15 & -0.16 & -0.16 & -0.37 & -0.22 & \\
\hline \multicolumn{8}{|c|}{$\mathrm{CH}_{3} \mathrm{I}\left(\mathrm{nmol} \mathrm{m}^{-2} h^{-1}\right)$} \\
\hline Air-sea flux & -0.15 & -0.37 & -0.39 & -0.51 & -0.41 & -0.39 & -0.5 to $-1.4^{\mathrm{d}}$ \\
\hline $\mathrm{ACH}_{3} \mathrm{I}$ & -0.02 & -0.07 & -0.16 & -0.31 & -1.3 & -0.53 & \\
\hline
\end{tabular}

where $\left[\mathrm{Cl}^{-}\right]$is the molar concentration of $\mathrm{Cl}^{-}\left(\mathrm{pmol} \mathrm{l}^{-1}\right)$ in seawater. The chloride substitution rate constants $\mathrm{kCH}_{3} \mathrm{Br}$

Table 3. Air-Sea Flux and Chloride Substitution Rate per Unit Area in the Mixed Layer of the Ocean Surface ${ }^{\mathrm{a}}$

${ }^{\text {a }}$ Positive values indicate addition to the mixed layer (air-to-sea influx and chloride substitution production); negative values indicate removal from the mixed layer (sea-to-air efflux and chloride substitution loss). Abbreviations are as follows: $\mathrm{SA}$, subarctic water; $\mathrm{ST}_{\mathrm{N}}$, northern subtropical water; $\mathrm{ST}_{\mathrm{S}}$, southern subtropical water; $\mathrm{TW}_{\mathrm{N}}$, northern transition water; and $\mathrm{TW}_{\mathrm{S}}$, southern transition water. See section 3.2 for water mass details.

${ }^{\mathrm{b}}$ See Khalil et al. [1999], Moore [2000], and Yoshida et al. [2004].

${ }^{\mathrm{c}}$ See Lobert et al. [1995], Groszko and Moore [1998], and King et al. [2002].

${ }^{\mathrm{d}}$ See Bell et al. [2002] and Butter et al. [2007]. 
Table 4. Average Ranges of Different VOC Concentrations in Surface Seawater ${ }^{\mathrm{a}}$

\begin{tabular}{|c|c|c|c|c|c|c|}
\hline & $\mathrm{SA}\left(44-49^{\circ} \mathrm{N}\right)$ & $\mathrm{TW}_{\mathrm{N}}\left(40-44^{\circ} \mathrm{N}\right)$ & $\mathrm{TW}_{\mathrm{S}}\left(32-40^{\circ} \mathrm{N}\right)$ & $\mathrm{ST}_{\mathrm{N}}\left(25-32^{\circ} \mathrm{N}\right)$ & $\mathrm{ST}_{\mathrm{S}}\left(12-25^{\circ} \mathrm{N}\right)$ & All $\left(12-49^{\circ} \mathrm{N}\right)$ \\
\hline $\mathrm{CH}_{3} \mathrm{Cl}\left(\mathrm{pmol} \mathrm{l}^{-1}\right)$ & $62-93(74)$ & $62-156(97)$ & $67-132(86)$ & $66-89(72)$ & 84-144 (117) & $62-156(93)$ \\
\hline $\mathrm{CH}_{3} \mathrm{Br}\left(\mathrm{pmol} \mathrm{l}^{-1}\right)$ & $1.3-2.8(1.8)$ & $1.7-7.5(3.3)$ & $0.92-2.5(1.3)$ & $0.72-1.2(0.81)$ & $0.59-0.85(0.72)$ & $0.59-7.5(1.9)$ \\
\hline $\mathrm{CH}_{3} \mathrm{I}\left(\mathrm{pmol} \mathrm{l}^{-1}\right)$ & $3.6-12(5.4)$ & $4.3-15(7.0)$ & $2.9-7.9(5.4)$ & $4.4-6.7(5.2)$ & $5.9-12(9.2)$ & $2.9-15(6.6)$ \\
\hline HCFC-22( $\left.\mathrm{pmol} \mathrm{l}^{-1}\right)$ & $9.2-12(11)$ & $7.4-12(8.9)$ & $5.4-8.1(6.3)$ & $5.5-5.8(5.7)$ & $4.8-5.5(5.2)$ & $4.8-12(7.7)$ \\
\hline
\end{tabular}

${ }^{a}$ Abbreviations are as follows: SA, subarctic water; $\mathrm{ST}_{\mathrm{N}}$, northern subtropical water; $\mathrm{ST}_{\mathrm{S}}$, southern subtropical water; $\mathrm{TW}_{\mathrm{N}}$, northern transition water; and $\mathrm{TW}_{\mathrm{S}}$, southern transition water. See section 3.2 for water mass details.

and $\mathrm{kCH}_{3} \mathrm{I}\left(1 \mathrm{~mol}^{-1} \mathrm{~s}^{-1}\right)$ were obtained from Elliott and Rowland [1993] and Jones and Carpenter [2007], respectively, as:

$$
\begin{gathered}
\mathrm{kCH}_{3} \mathrm{Br}=\left(9.53 \times 10^{12}\right) \cdot \operatorname{Exp}(-12679 / \mathrm{T}) \\
\mathrm{kCH}_{3} \mathrm{I}=\left(3.66 \times 10^{13}\right) \cdot \operatorname{Exp}(-13317 / \mathrm{T}),
\end{gathered}
$$

where $\mathrm{T}$ is seawater temperature $\left({ }^{\circ} \mathrm{C}\right)$. Production rate of $\mathrm{CH}_{3} \mathrm{Cl}$ per unit volume $\left(\mathrm{VCH}_{3} \mathrm{Cl}\right.$; pmol $\left.\mathrm{l}^{-1} \mathrm{~h}^{-1}\right)$ as a result of chloride substitution of $\mathrm{CH}_{3} \mathrm{Br}$ and $\mathrm{CH}_{3} \mathrm{I}$ can be calculated by the following equation:

$$
\mathrm{VCH}_{3} \mathrm{Cl}=-\left(\mathrm{VCH}_{3} \mathrm{Br}+\mathrm{VCH}_{3} \mathrm{I}\right) .
$$

The chloride substitution (loss or production) rate of $\mathrm{CH}_{3} \mathrm{X}$ per unit area $\left(\mathrm{ACH}_{3} \mathrm{X} ; \mathrm{nmol} \mathrm{m}^{-2} \mathrm{~h}^{-1}\right)$ in the mixed layer was defined by:

$$
\mathrm{ACH}_{3} \mathrm{X}=\mathrm{VCH}_{3} \mathrm{X} \cdot \mathrm{z}
$$

where $\mathrm{z}$ is the mixed layer depth (MLD; $\mathrm{m}$ ), defined as the depth where the potential density has increased by $0.125 \mathrm{~kg} \mathrm{~m}^{-3}$ compared to that at the reference depth of $10 \mathrm{~m}$. Positive and negative values of $\mathrm{ACH}_{3} \mathrm{X}$ mean production and loss of $\mathrm{CH}_{3} \mathrm{X}$ via chloride substitution in the mixed layer, respectively.

[20] The averages of air-sea flux and chloride substitution rate per unit area from this study are summarized in Table 3. In $\mathrm{TW}_{\mathrm{N}}, \mathrm{TW}_{\mathrm{S}}, \mathrm{ST}_{\mathrm{N}}$, and $\mathrm{ST}_{\mathrm{S}}$ waters, the average sea-to-air efflux of $\mathrm{CH}_{3} \mathrm{Cl}\left(4.1-5.5 \mathrm{nmol} \mathrm{m}^{-2} \mathrm{~h}^{-1}\right)$ was higher than the annual global oceanic mean efflux of $2.0-4.1 \mathrm{nmol} \mathrm{m}^{-2} \mathrm{~h}^{-1}$ [Khalil et al., 1999; Moore, 2000; Yoshida et al., 2004]. In these same waters of our study, the production of $\mathrm{CH}_{3} \mathrm{Cl}$ via chloride substitution $\left(0.21-1.7 \mathrm{nmol} \mathrm{m}^{-2} \mathrm{~h}^{-1}\right)$ compensated for $5-32 \%$ of the sea-to-air efflux.

[21] On average, the ocean surface in our study area was a weak source of $\mathrm{CH}_{3} \mathrm{Br}$, with an average sea-to-air efflux of $0.02 \mathrm{nmol} \mathrm{m}^{-2} \mathrm{~h}^{-1}$, most of which was attributable to the strong efflux of $0.20 \mathrm{nmol} \mathrm{m}{ }^{-2} \mathrm{~h}^{-1}$ in $\mathrm{TW}_{\mathrm{N}}$ water. On annual global average, the ocean surface is estimated to be a net sink for $\mathrm{CH}_{3} \mathrm{Br}$, with a mean influx of 0.03 $0.07 \mathrm{nmol} \mathrm{m}{ }^{-2} \mathrm{~h}^{-1}$ [Lobert et al., 1995; Groszko and Moore, 1998; King et al., 2002]. The chloride substitution loss of $\mathrm{CH}_{3} \mathrm{Br}\left(0.03 \mathrm{nmol} \mathrm{m} \mathrm{h}^{-2} \mathrm{~h}^{-1}\right)$ in SA water was comparable to the air-to-sea influx $\left(0.03 \mathrm{nmol} \mathrm{m}^{-2} \mathrm{~h}^{-1}\right)$. In contrast, the chloride substitution loss in $\mathrm{ST}_{\mathrm{N}}$ and $\mathrm{ST}_{\mathrm{S}}$ waters $\left(0.16-0.37 \mathrm{nmol} \mathrm{m}^{-2} \mathrm{~h}^{-1}\right)$ was 3-12 times the air-to-sea influx $\left(0.03-0.05 \mathrm{nmol} \mathrm{m}^{-2} \mathrm{~h}^{-1}\right)$. This suggests that chloride substitution loss has largely contributed to the decline of $\mathrm{CH}_{3} \mathrm{Br}$ levels to undersaturation in $\mathrm{ST}_{\mathrm{N}}$ and $\mathrm{ST}_{\mathrm{S}}$ waters.

[22] The average sea-to-air efflux of $\mathrm{CH}_{3} \mathrm{I}\left(0.39 \mathrm{nmol} \mathrm{m}^{-2}\right.$ $\mathrm{h}^{-1}$ ) in our study area was a little smaller than the averaged global oceanic efflux of $0.50 \mathrm{nmol} \mathrm{m}{ }^{-2} \mathrm{~h}^{-1}$ [Bell et al., 2002]. The total of sea-to-air efflux and chloride substitution loss of $\mathrm{CH}_{3} \mathrm{I}$ increased going southward from SA water $\left(0.17 \mathrm{nmol} \mathrm{m}^{-2} \mathrm{~h}^{-1}\right)$ to $\mathrm{ST}_{\mathrm{S}}$ water $\left(1.7 \mathrm{nmol} \mathrm{m}^{-2} \mathrm{~h}^{-1}\right)$. This indicates that the net production of $\mathrm{CH}_{3} \mathrm{I}$ in the subtropical water is much greater than in the subarctic water.

\subsection{Relationships Between Seawater VOC Concentrations and SST}

[23] Previous studies have given relationships between saturation anomalies for $\mathrm{CH}_{3} \mathrm{Cl}$ and $\mathrm{CH}_{3} \mathrm{Br}$ and $\mathrm{SST}$. As for $\mathrm{CH}_{3} \mathrm{I}$, saturation anomaly is significantly affected by the change of $p \mathrm{CH}_{3} \mathrm{I}_{\text {air }}(0.30-2.5 \mathrm{pptv})$. Production and loss of $\mathrm{CH}_{3} \mathrm{I}$ in seawater are reflected in the change of $\mathrm{CCH}_{3} \mathrm{I}$ rather than $\mathrm{SCH}_{3} \mathrm{I}$. To examine production and loss of $\mathrm{CH}_{3} \mathrm{X}$, we use the relationships between CVOC and SST. The averages and ranges of the CVOCs are listed in Table 4. The relationships between $\mathrm{C}_{\mathrm{VOC}}$ and SST are shown in Figure 5.
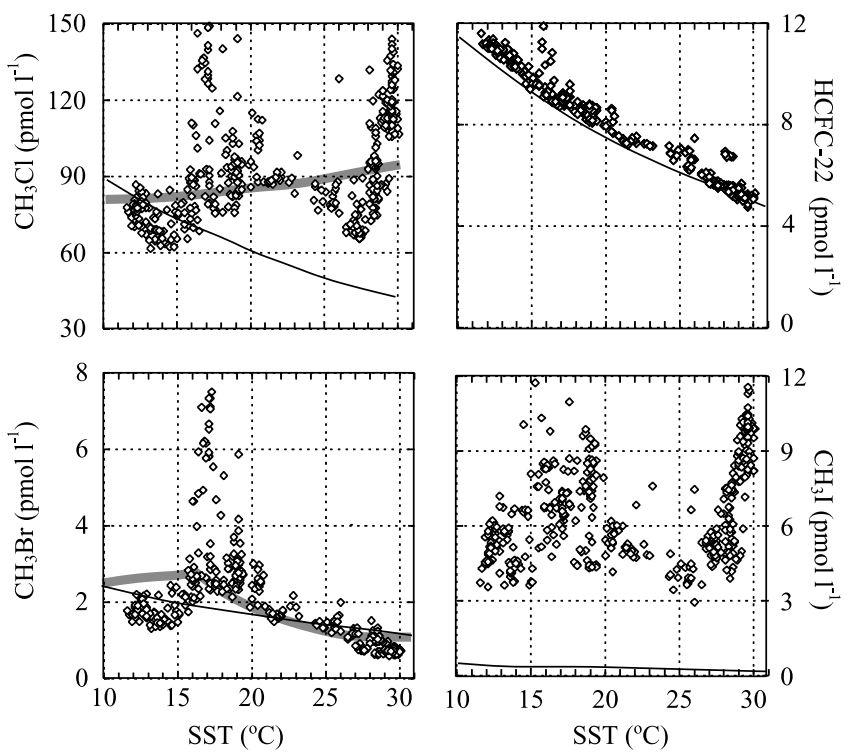

Figure 5. Relationship between VOC concentrations (CVOCs) and sea surface temperature (SST). The solid thin lines indicate the equilibrium concentrations with respect to the average partial pressures for $\mathrm{pCH}_{3} \mathrm{Cl}_{\text {air }}(583 \mathrm{pptv})$, $p \mathrm{CH}_{3} \mathrm{Br}_{\text {air }}$ (11 pptv), $p \mathrm{CH}_{3} \mathrm{I}_{\text {air }}$ (0.99 pptv), and pHCFC-22 air (203 pptv). The equilibrium concentrations were calculated by equation (3). Bold gray lines in the $\mathrm{CH}_{3} \mathrm{Cl}$ and $\mathrm{CH}_{3} \mathrm{Br}$ panels present empirical relationships on the basis of $\mathrm{SCH}_{3} \mathrm{Cl}(\%)=-24.1+0.159 \mathrm{~T}^{2}$ [Khalil et al., 1999] and $\mathrm{SCH}_{3} \mathrm{Br}(\%)=0.17065 \mathrm{~T}^{2}+1.91413 \mathrm{~T}-33.85496$ for $\mathrm{T}<16^{\circ} \mathrm{C}$, and $\mathrm{SCH}_{3} \mathrm{Br}(\%)=0.48994 \mathrm{~T}^{2}-26.70125 \mathrm{~T}+$ 349.14043 for $\mathrm{T}>16^{\circ} \mathrm{C}$ [King et al., 2002]. 
The concentrations of individual VOCs in seawater at equilibrium with the respective average $p \mathrm{VOC}_{\text {air }}$ were calculated by equation (3) and shown as thin solid lines in Figure 5. Bold gray lines in the $\mathrm{CH}_{3} \mathrm{Cl}$ and $\mathrm{CH}_{3} \mathrm{Br}$ panels present empirical relationships on the basis of: $\mathrm{SCH}_{3} \mathrm{Cl}(\%)=-24.1+0.159 \mathrm{~T}^{2}$ [Khalil et al., 1999] and $\mathrm{SCH}_{3} \mathrm{Br}(\%)=0.17065 \mathrm{~T}^{2}+$ $1.91413 \mathrm{~T}-33.85496$ for $\mathrm{T}<16^{\circ} \mathrm{C} ; \mathrm{SCH}_{3} \mathrm{Br}(\%)=$ $0.48994 \mathrm{~T}^{2}-26.70125 \mathrm{~T}+349.14043$ for $\mathrm{T}>16^{\circ} \mathrm{C}$ ) [King et al., 2002]. $\mathrm{SCH}_{3} \mathrm{Cl}$ and $\mathrm{SCH}_{3} \mathrm{Br}$ are the saturation anomalies for $\mathrm{CH}_{3} \mathrm{Cl}$ and $\mathrm{CH}_{3} \mathrm{Br}$, respectively, and $\mathrm{T}=$ SST $\left({ }^{\circ} \mathrm{C}\right)$. Saturation anomalies of the empirical equations were converted to CVOCs (pmol $\mathrm{l}^{-1}$ ) by equations (1) and (3) using a respective constant $p \mathrm{VOC}_{\mathrm{air}}$ value. The average $p \mathrm{CH}_{3} \mathrm{Cl}_{\text {air }}$ (583 pptv) during this cruise was used to convert the empirical equation of $\mathrm{SCH}_{3} \mathrm{Cl}$ by Khalil et al. [1999]. The atmospheric $\mathrm{CH}_{3} \mathrm{Br}$ level has been declined during the phaseout period owing to the Montreal Protocol [Yokouchi et al., 2002]. The average $p \mathrm{CH}_{3} \mathrm{Br}_{\text {air }}$ of $11 \mathrm{pptv}$ measured during the prephaseout period was used to convert the empirical equation of $\mathrm{SCH}_{3} \mathrm{Br}$ by King et al. [2002].

\subsection{1. $\mathrm{CH}_{3} \mathrm{Cl}$ Versus SST}

[24] The scatterplot of $\mathrm{CCH}_{3} \mathrm{Cl}$ versus SST has high values and much scatter both in the SST range from 16 to $20^{\circ} \mathrm{C}\left(\mathrm{TW}_{\mathrm{N}}\right.$ water) and from 27 to $30^{\circ} \mathrm{C}\left(\mathrm{ST}_{\mathrm{N}}\right.$ and $\mathrm{ST}_{\mathrm{S}}$ waters) (Figure 5). Between SSTs of 16 and $20^{\circ} \mathrm{C}$, where high concentrations of chlorophyll-a were observed, the average $\mathrm{CCH}_{3} \mathrm{Cl}\left(97 \mathrm{pmol} \mathrm{l}^{-1}\right)$ and the maximum $\mathrm{CCH}_{3} \mathrm{Cl}$ $\left(156 \mathrm{pmol}^{-1}\right)$ are 1.1 and 1.8 times that of the average value $\left(84 \mathrm{pmol} \mathrm{l}^{-1}\right)$ calculated from the empirical equation in the same SST range. As direct evidence for the production of $\mathrm{CH}_{3} \mathrm{Cl}$ from phytoplankton has been reported [e.g., Scarratt and Moore, 1996, 1998], we considered that the high $\mathrm{CCH}_{3} \mathrm{Cl}$ in $\mathrm{TW}_{\mathrm{N}}$ was due to enhanced production by phytoplankton.

[25] In the SST range $27-30^{\circ} \mathrm{C}$, where the chlorophyll-a concentrations were low, $\mathrm{CCH}_{3} \mathrm{Cl}$ sharply increased from $66 \mathrm{pmol}^{-1}$ to $144 \mathrm{pmol}^{-1}$ with the SST rise. The maximum $\mathrm{CCH}_{3} \mathrm{Cl}\left(144 \mathrm{pmol}^{-1}\right)$ observed at $\mathrm{SST}=30^{\circ} \mathrm{C}$ is 1.5 times the value of 95 pmol $1^{-1}$ calculated with the empirical equation at the same SST [Khalil et al., 1999]. Chloride substitutions of $\mathrm{CH}_{3} \mathrm{Br}$ and $\mathrm{CH}_{3} \mathrm{I}$ has been regarded as an important abiotic process of $\mathrm{CH}_{3} \mathrm{Cl}$ production in seawater [Elliott and Rowland, 1993; Jones and Carpenter, 2007], and was estimated to account for $\sim 40-75 \%$ of the global oceanic source of $\mathrm{CH}_{3} \mathrm{Cl}$ [Moore et al., 1996]. The chloride substitution production of $\mathrm{CH}_{3} \mathrm{Cl}\left(1.7 \mathrm{nmol} \mathrm{m}^{-2} \mathrm{~h}^{-1}\right)$ in $\mathrm{ST}_{\mathrm{S}}$ water is estimated to compensate for $31 \%$ of the seato-air efflux (5.5 nmol m $\left.\mathrm{m}^{-2} \mathrm{~h}^{-1}\right)$, even though the determination of MLD could directly influence the flux calculation as expressed in equation (9).

[26] This result implies that there is still a large source of $\mathrm{CH}_{3} \mathrm{Cl}$ in the surface $\mathrm{ST}_{\mathrm{S}}$ water other than chloride substitution production; for example, photochemical reactions involving colored dissolved organic matter (CDOM) in seawater [Moore, 2008]. Moore [2008] reported that terrestrially derived humic-like CDOM in a chloride solution yielded $\mathrm{CH}_{3} \mathrm{Cl}$ through a photochemical process. He also found that high-molecular-weight (HMW) DOM of $1 \mathrm{kDa}$ to $0.2 \mu \mathrm{m}$ in size, which had been extracted from subsurface water (at $600 \mathrm{~m}$ depth) in the subtropical North Pacific, showed some ability to enhance photochemical production of $\mathrm{CH}_{3} \mathrm{Cl}$, while HMW-DOM from surface seawater did not.
[27] It should be mentioned that Moore [2008] found that surface seawater with no HMW-DOM supplement produced $\mathrm{CH}_{3} \mathrm{Cl}$ at a rate of $\sim 5 \mathrm{pmol} \mathrm{l}^{-1} \mathrm{~h}^{-1}$ after irradiation by a solar simulator with wavelengths between 300 and $800 \mathrm{~nm}$. This result implies the existence of certain kind of DOM, other than HMW-DOM, involving the photochemical production of $\mathrm{CH}_{3} \mathrm{Cl}$ in seawater, that is, low-molecular-weight DOM $(\mathrm{LMW}-\mathrm{DOM})<1 \mathrm{kDa}$ in size which accounts for a large fraction $(65-80 \%)$ of the bulk DOM from surface to deep waters [Ogawa and Tanoue, 2003]. Humic-like DOM would be necessary for the photochemical production of $\mathrm{CH}_{3} \mathrm{Cl}$ as referred above. In the surface layer of the open ocean, in situ production of humic-like fluorescent DOM (FDOM; excitation maximum at $\lambda=320 \mathrm{~nm}$ ), which occurs simultaneously with photochemical degradation, was ascertained by field observation [Yamashita and Tanoue, 2008]. We suggest that it is possible that humic-like LMW-FDOM, which can be produced in the surface of the open ocean, is capable of producing $\mathrm{CH}_{3} \mathrm{Cl}$ through photochemical reactions, and that the photochemical production rate of $\mathrm{CH}_{3} \mathrm{Cl}$ by LMW-FDOM at the surface (probably 5 pmol $\mathrm{l}^{-1} \mathrm{~h}^{-1}$ in maximum) is considerably higher than the chloride substitution production rate of $0.04 \mathrm{pmol} \mathrm{l}^{-1} \mathrm{~h}^{-1}$ observed in $\mathrm{ST}_{\mathrm{S}}$ water of the NW Pacific. If LMW-FDOM is biologically produced by temperature-dependent enzymatic reactions in seawater, the higher SST could lead the higher photochemical production rate of $\mathrm{CH}_{3} \mathrm{Cl}$. Photochemical production as well as chloride substitution would contribute to production of $\mathrm{CH}_{3} \mathrm{Cl}$ in the surface of subtropical waters.

\subsection{2. $\mathrm{CH}_{3} \mathrm{Br}$ Versus SST}

[28] In the SST range $16-20^{\circ} \mathrm{C}\left(\mathrm{TW}_{\mathrm{N}}\right.$ water), we found a significant peak of $\mathrm{CCH}_{3} \mathrm{Br}$ (up to $7.5 \mathrm{pmol}^{-1}$ ), and the average $\mathrm{CCH}_{3} \mathrm{Br}$ of $3.3 \mathrm{pmol}^{-1}$ is close to the value calculated from the empirical equation $\left(2.9 \mathrm{pmol}^{-1}\right)$ for the same SST range during the prephaseout period. The average $\mathrm{CCH}_{3} \mathrm{Br}$ of $1.8 \mathrm{pmol}^{-1}$ within SST range $11-16^{\circ} \mathrm{C}$ and $0.72 \mathrm{pmol}^{-1}$ within $28-30^{\circ} \mathrm{C}$ are lower than the values of $3.3 \mathrm{pmol}^{-1}$ and $1.3 \mathrm{pmol}^{-1}$ calculated from the empirical equation for the same SST ranges, respectively.

[29] We compared $\mathrm{CCH}_{3} \mathrm{Cl}$ and $\mathrm{CCH}_{3} \mathrm{Br}$ in $\mathrm{SA}$ and $\mathrm{TW}_{\mathrm{N}}$ waters (Figure 6a). We found strong correlations between $\mathrm{CCH}_{3} \mathrm{Br}$ and $\mathrm{CCH}_{3} \mathrm{Cl}$ in SA water $\left(r^{2}=0.78\right)$ and in $\mathrm{TW}_{\mathrm{N}}$ water $\left(r^{2}=0.85\right)$. A strong correlation $\left(r^{2}=0.89\right)$ between concentrations of these two compounds has been also found in subarctic northwest Atlantic waters cooler than $23^{\circ} \mathrm{C}$, and attributed to similarities in biological production and/or loss of these gases [MacDonald and Moore, 2007]. There is no correlation between $\mathrm{CCH}_{3} \mathrm{Cl}$ and $\mathrm{CCH}_{3} \mathrm{Br}\left(r^{2}=0.15\right)$ in $\mathrm{ST}_{\mathrm{N}}$ and $\mathrm{ST}_{\mathrm{S}}$ waters where the biological production was low based on chlorophyll-a concentration data. It is clear that production and loss processes of $\mathrm{CH}_{3} \mathrm{Br}$ in ST waters are different from those of $\mathrm{CH}_{3} \mathrm{Cl}$.

\subsection{3. $\mathrm{CH}_{3} \mathrm{I}$ Versus SST}

[30] As with $\mathrm{CH}_{3} \mathrm{Cl}$, the plot of $\mathrm{CCH}_{3} \mathrm{I}$ versus SST had concentration peaks both for SST $=16-20^{\circ} \mathrm{C}$ (up to $15 \mathrm{pmol}^{-1}$ ) and for SST $=27-30^{\circ} \mathrm{C}$ (up to $12 \mathrm{pmol} \mathrm{l}^{-1}$ ). Similar substantial increases of $\mathrm{CH}_{3} \mathrm{I}$ (up to 9.7 pmol $\mathrm{l}^{-1}$ ) have been measured in the mixed water region of the Atlantic $\left(40^{\circ} \mathrm{S}\right)$, where substantially higher chlorophyll-a concentrations have been also detected [Schall et al., 1997]. There is direct evidence for the production of $\mathrm{CH}_{3} \mathrm{I}$ from phyto- 
(a)

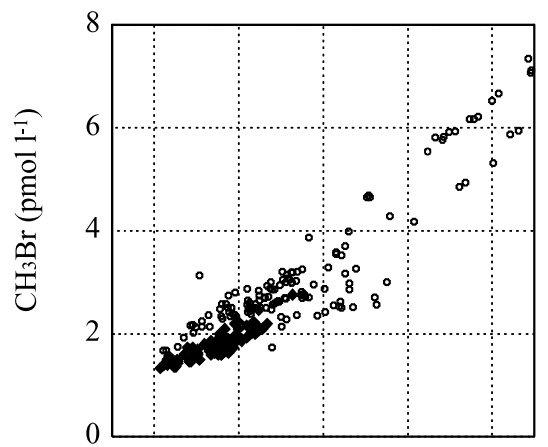

(b)

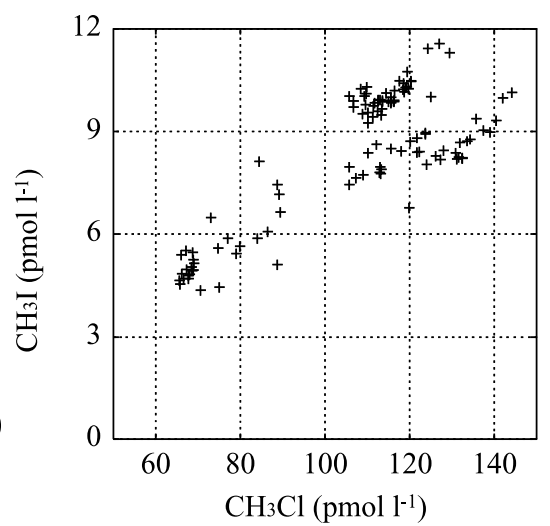

Figure 6. Scatterplots of methyl halide concentrations. (a) $\mathrm{CCH}_{3} \mathrm{Cl}$ versus $\mathrm{CCH}_{3} \mathrm{Br}$ in $\mathrm{SA}$ (subarctic) water (diamonds) and $\mathrm{TW}_{\mathrm{N}}$ (northern transition) water (circles). (b) $\mathrm{CCH}_{3} \mathrm{Cl}$ versus $\mathrm{CCH}_{3} \mathrm{I}$ in $\mathrm{ST}_{\mathrm{N}}$ (northern subtropical water) and $\mathrm{ST}_{\mathrm{S}}$ (southern subtropical water) (pluses).

plankton [e.g., Manley and dela Cuesta, 1997; Scarratt and Moore, 1998]. We considered that high $\mathrm{CCH}_{3} \mathrm{I}$ in SST range $16-20^{\circ} \mathrm{C}\left(\mathrm{TW}_{\mathrm{N}}\right.$ water) was due to enhanced production by phytoplankton. For $\mathrm{SST}=27-30^{\circ} \mathrm{C}\left(\mathrm{ST}_{\mathrm{N}}\right.$ and $\mathrm{ST}_{\mathrm{S}}$ waters $)$, we found that $\mathrm{CCH}_{3} \mathrm{I}$ sharply increased from $4.4 \mathrm{pmol}^{-1}$ to $12 \mathrm{pmol} \mathrm{l}^{-1}$ with the increase in SST. Similar significant increases ranging from 6.0 to $12 \mathrm{pmol}^{-1}$ have been found in summer in the subtropical South Atlantic $\left(19^{\circ} \mathrm{S}\right)$ [Happell and Wallace, 1996].

[31] The significant increase of $\mathrm{CCH}_{3} \mathrm{I}$ with SST rise in $\mathrm{ST}_{\mathrm{N}}$ and $\mathrm{ST}_{\mathrm{S}}$ waters could be due to photochemical production of $\mathrm{CH}_{3} \mathrm{I}$ for the following reasons. Moore and Zafiriou [1994] proposed for $\mathrm{CH}_{3} \mathrm{I}$ production a radical recombination mechanism of methyl radicals formed from the photolysis of humic materials with I radical formed from the photochemical oxidation of $\mathrm{I}^{-}$. Dissolved $\mathrm{I}^{-}$concentrations in oligotrophic subtropical waters are much higher than those in nutrient rich, subpolar and polar waters, because $\mathrm{IO}_{3}^{-}$would be reduced to $\mathrm{I}^{-}$in the absence of $\mathrm{NO}_{3}^{-}$ by enzymatic reaction [Campos et al., 1999]. Chuck et al. [2005] also suggested that photochemical production of $\mathrm{CH}_{3} \mathrm{I}$ is associated with nitrate reductase activity which could reduce $\mathrm{IO}_{3}^{-}$. In general, enzymatic reactions are highly dependent on temperature. Therefore, the higher SST in subtropical water would lead to a higher photochemical production rate of $\mathrm{CH}_{3} \mathrm{I}$. The averaged photochemical production rate of $\mathrm{CH}_{3} \mathrm{I}$ within the mixed layer of tropical seawater $(M L D=30 \mathrm{~m})$ is estimated to be $1 \mathrm{nmol} \mathrm{m}^{-2} \mathrm{~h}^{-1}$ [Richter and Wallace, 2004], which is close to the total of sea- to-air efflux and chloride substitution loss $\left(1.7 \mathrm{nmol} \mathrm{m}^{-1} \mathrm{~h}^{-1}\right)$ from our results in $\mathrm{ST}_{\mathrm{S}}$ water.

[32] Other than photochemical production, the importance of biological production of $\mathrm{CH}_{3} \mathrm{I}$ by Prochlorococcus, a genus of cyanobacteria that predominates in subtropical waters, was suggested by Smythe-Wright et al. [2006]. Although Prochlorococcus would directly produce $\mathrm{CH}_{3} \mathrm{I}$, it may also contribute to the biological reduction of $\mathrm{IO}_{3}^{-}$to $\mathrm{I}^{-}$similar to Synechococcus (a genus of cyanobacteria) [Wong et al., 2002].

[33] Wang et al. [2009] pointed out two reasons why photochemical reactions can account for the positive correlation $\left(r^{2}=0.37\right)$ that they observed in the North Atlantic $\left(37-59^{\circ} \mathrm{N}\right)$ between $\mathrm{CH}_{3} \mathrm{I}$ concentration and water temperature. First, higher temperature could promote biological CDOM formation, and second, photochemical reaction rate could be positively influenced by temperature. We supposed that higher SST and stronger light intensity in subtropical waters have promoted $\mathrm{CH}_{3} \mathrm{I}$ production through photochemical pathway and biological pathways by direct emission of $\mathrm{CH}_{3} \mathrm{I}$ from Prochlorococcus and/or by formations of
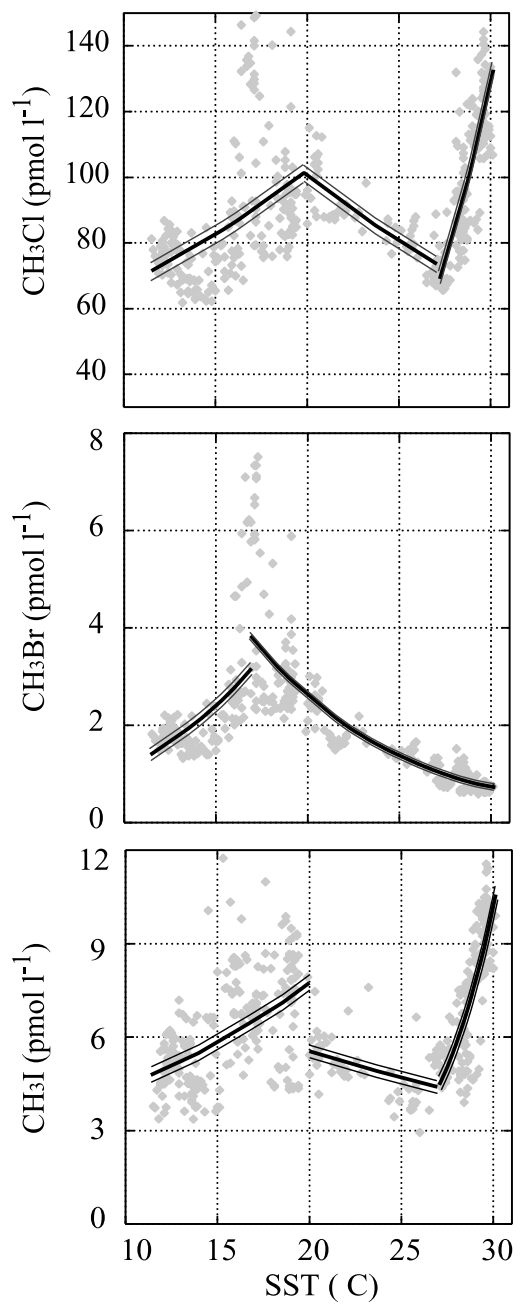

Figure 7. Empirical regression curves (bold solid lines) of methyl halide concentrations $\left(\mathrm{CCH}_{3} \mathrm{X}\right)$ versus sea surface temperature (SST) with $95 \%$ confidence limits (gray lines). The equation parameters are in Table 5. 
Table 5. Empirical Regression Formulas of Methyl Halides Concentrations in Surface Seawater as a Function of Sea Surface Temperature $^{\mathrm{a}}$

\begin{tabular}{ccrc}
\hline Methyl Halides $\left(\mathrm{pmol} \mathrm{l}^{-1}\right)$ & \multicolumn{1}{c}{ Formula } & SST Range & $r^{2}$ \\
\hline $\mathrm{CCH}_{3} \mathrm{Cl}$ & $43.9 \cdot \exp (0.0420 \cdot \mathrm{T})$ & $11-20^{\circ} \mathrm{C}$ & 0.20 \\
& $244 \cdot \exp (-0.0443 \cdot \mathrm{T})$ & $20-27^{\circ} \mathrm{C}$ & 0.48 \\
& $0.147 \cdot \exp (0.226 \cdot \mathrm{T})$ & $27-30^{\circ} \mathrm{C}$ & 0.69 \\
$\mathrm{CCH}_{3} \mathrm{Br}$ & $0.27 \cdot \exp (0.144 \cdot \mathrm{T})$ & $11-17^{\circ} \mathrm{C}$ & 0.43 \\
& $34.2 \cdot \exp (-0.129 \cdot \mathrm{T})$ & $17-30^{\circ} \mathrm{C}$ & 0.74 \\
$\mathrm{CCH}_{3} \mathrm{I}$ & $2.5 \cdot \exp (0.0565 \cdot \mathrm{T})$ & $11-20^{\circ} \mathrm{C}$ & 0.19 \\
& $11 \cdot \exp (-0.0346 \cdot \mathrm{T})$ & $20-27^{\circ} \mathrm{C}$ & 0.16 \\
& $0.0018 \cdot \exp (0.288 \cdot \mathrm{T})$ & $27-30^{\circ} \mathrm{C}$ & 0.66 \\
\hline
\end{tabular}

${ }^{\mathrm{a}} \mathrm{SST}$, sea surface temperature. $\mathrm{T}=\mathrm{SST}\left({ }^{\circ} \mathrm{C}\right)$. Here $r^{2}$ values are the correlations between the observed values and the calculated values from the regression formulas.

intermediates of photochemical reactions such as $\mathrm{I}^{-}$and LMW-FDOM as a source of methyl radical. Furthermore, high correlation between $\mathrm{CCH}_{3} \mathrm{I}$ and $\mathrm{CCH}_{3} \mathrm{Cl}\left(r^{2}=0.67\right)$ in $\mathrm{ST}_{\mathrm{N}}$ and $\mathrm{ST}_{\mathrm{S}}$ waters (Figure $6 \mathrm{~b}$ ) implies a similarity in the production pathways of the 2 methyl halides.

\subsection{Regression Analysis of Methyl Halide Concentrations}

[34] Empirical regression curves of $\mathrm{CH}_{3} \mathrm{X}$ concentrations are expressed as exponential functions of SST (Figure 7) and their formulas are listed in Table 5. As with the $\mathrm{CH}_{3} \mathrm{Cl}$ and $\mathrm{CH}_{3} \mathrm{I}$ concentration data presented above, the regression formulas are divided into $3 \mathrm{SST}$ ranges of $11-20^{\circ} \mathrm{C}$ (SA and $\mathrm{TW}_{\mathrm{N}}$ waters $), 20-27^{\circ} \mathrm{C}\left(\mathrm{TW}_{\mathrm{S}}\right.$ water), and $27-30^{\circ} \mathrm{C}\left(\mathrm{ST}_{\mathrm{N}}\right.$ and $\mathrm{ST}_{\mathrm{S}}$ waters). The $\mathrm{CH}_{3} \mathrm{Br}$ regression formula is split at $\mathrm{SST}=17^{\circ} \mathrm{C}$, where the peak $\mathrm{CCH}_{3} \mathrm{Br}$ was found in $\mathrm{TW}_{\mathrm{N}}$ water. Tokarczyk and Moore [2006] point out that the saturation anomaly of $\mathrm{CH}_{3} \mathrm{Br}$ in surface seawater cannot be predicted from the temperature data only in temperate areas with high biological activity where production and degradation processes of $\mathrm{CH}_{3} \mathrm{Br}$ are likely to be more dynamic than SST change. Further research on the $\mathrm{CH}_{3} \mathrm{X}$ distributions in various ocean waters for all seasons is needed for the precise estimation of global distributions of $\mathrm{CH}_{3} \mathrm{X}$ and their oceanic air-sea flux.

\section{Summary}

[35] The partial pressures of $\mathrm{CH}_{3} \mathrm{X}(\mathrm{X}=\mathrm{Cl}, \mathrm{Br}$, and I) in the surface seawater of the NW Pacific from subarctic to subtropical regions were found to vary spatially. In the northern transition water (mixed water region), which had high biological activity, high levels for the $3 \mathrm{CH}_{3} \mathrm{X}$ were frequently observed because phytoplankton could have contributed to their production. In the subtropical water, which had very low biological production, the latitudinal distributions of $p \mathrm{CH}_{3} \mathrm{Cl}_{\text {water }}$ and $p \mathrm{CH}_{3} \mathrm{I}_{\text {water }}$ had a peak between $15^{\circ} \mathrm{N}$ and $20^{\circ} \mathrm{N}$ where high SST values (up to $30^{\circ} \mathrm{C}$ ) were observed. We found that $\mathrm{CCH}_{3} \mathrm{Cl}$ and $\mathrm{CCH}_{3} \mathrm{I}$ sharply increased with an SST rise in the subtropical water. We propose that photochemical production of $\mathrm{CH}_{3} \mathrm{I}$ and $\mathrm{CH}_{3} \mathrm{Cl}$ largely contributed to their enrichment in the surface of subtropical water. This may be the result of temperaturedependent enzymatic reactions producing intermediates of photochemical reactions such as LMW-FDOM and $\mathrm{I}^{-}$.
[36] We calculated empirical regression formulas for $\mathrm{CH}_{3} \mathrm{X}$ concentrations in surface seawater as exponential functions of SST. Regression formulas of $\mathrm{CH}_{3} \mathrm{Cl}$ and $\mathrm{CH}_{3} \mathrm{I}$ were divided into 3 SST ranges corresponding to the oceanic frontal boundaries. The regression formula for $\mathrm{CH}_{3} \mathrm{Br}$ was split at SST $=17^{\circ} \mathrm{C}$. Further research on $\mathrm{CH}_{3} \mathrm{X}$ measurements in all seasons for various water types is needed for precise estimations of the global distributions of $\mathrm{CH}_{3} \mathrm{X}$ and their air-sea flux.

[37] Acknowledgments. We would like to thank the chief scientists, captain, and crews of Hakuho-maru (cruise KH-08-2). We would also like to thank J. Nishioka and T. Yoshimura for the chlorophyll-a data. This research has been supported by the Grant-in-Aid for Scientific Research in priority areas Western Pacific Air-Sea Interaction Study under grant 18067012. This research is a contribution to the Surface Ocean Lower Atmosphere Study Core Project of the International Geosphere-Biosphere Programme.

\section{References}

Amachi, S., Y. Kamagata, T. Kanagawa, and Y. Muramatsu (2001), Bacteria mediate methylation of iodine in marine and terrestrial environments, Appl. Environ. Microbiol., 67, 2718-2722, doi:10.1128/ AEM.67.6.2718-2722.2001.

Anbar, A. D., Y. L. Yung, and F. P. Chavez (1996), Methyl bromide: Ocean sources, ocean sinks, and climate sensitivity, Global Biogeochem. Cycles, 10, 175-190, doi:10.1029/95GB02743.

Bell, N., L. Hsu, D. J. Jacob, M. G. Schultz, D. R. Blake, J. H. Butler, D. B. King, J. M. Lobert, and E. Maier-Reimer (2002), Methyl iodide: Atmospheric budget and use as a tracer of marine convection in global models, J. Geophys. Res., 107(D17), 4340, doi:10.1029/2001JD001151.

Butler, J. H., D. B. King, J. M. Lobert, S. A. Montzka, S. A. Yvon-Lewis, B. D. Hall, N. J. Warwick, D. J. Mondeel, M. Aydin, and J. W. Elkins (2007), Oceanic distributions and emissions of short-lived halocarbons, Global Biogeochem. Cycles, 21, GB1023, doi:10.1029/2006GB002732.

Campos, M. L. A. M., R. Sanders, and T. Jickells (1999), The dissolved iodate and iodide distribution in the South Atlantic from the Weddell Sea to Brazil, Mar. Chem., 65, 167-175, doi:10.1016/S0304-4203(98) 00094-2.

Chameides, W. L., and D. D. Davis (1980), Iodine: Its possible role in tropospheric photochemistry, J. Geophys. Res., 85, 7383-7398, doi:10.1029/JC085iC12p07383.

Chuck, A. L., S. M. Turner, and P. S. Liss (2005), Oceanic distributions and air-sea fluxes of biogenic halocarbons in the open ocean, J. Geophys. Res., 110, C10022, doi:10.1029/2004JC002741.

Elliott, S., and F. S. Rowland (1993), Nucleophilic-substitution rates and solubilities for methyl halides in seawater, Geophys. Res. Lett., 20, 1043-1046, doi:10.1029/93GL01081.

Giese, B., F. Laturnus, F. C. Adams, and C. Wiencke (1999), Release of volatile iodinated $\mathrm{C}-1-\mathrm{C}-4$ hydrocarbons by marine macroalgae from various climate zones, Environ. Sci. Technol., 33, 2432-2439, doi:10.1021/es980731n

Groszko, W., and R. M. Moore (1998), Ocean-atmosphere exchange of methyl bromide: NW Atlantic and Pacific Ocean studies, J. Geophys. Res., 103, 16,737-16,741, doi:10.1029/98JD00111.

Happell, J. D., and D. W. R. Wallace (1996), Methyl iodide in the Greenland/Norwegian Seas and the tropical Atlantic Ocean: Evidence for photochemical production, Geophys. Res. Lett., 23, 2105-2108, doi:10.1029/ 96GL01764.

Hunter-Smith, R. J., P. W. Balls, and P. S. Liss (1983), Henry's law constants and the air-sea exchange of various low molecular weight halocarbon gases, Tellus, Ser. B, 35, 170-176, doi:10.1111/j.1600-0889.1983. tb00021.x

Jones, C. E., and L. J. Carpenter (2007), Chemical destruction of $\mathrm{CH}_{3} \mathrm{I}$, $\mathrm{C}_{2} \mathrm{H}_{5} \mathrm{I}, 1-\mathrm{C}_{3} \mathrm{H}_{7} \mathrm{I}$, and $2-\mathrm{C}_{3} \mathrm{H}_{7} \mathrm{I}$ in saltwater, Geophys. Res. Lett., 34, L13804, doi:10.1029/2007GL029775.

Khalil, M. A. K., R. M. Moore, D. B. Harper, J. M. Lobert, D. J. Erickson, V. Koropalov, W. T. Sturges, and W. C. Keene (1999), Natural emissions of chlorine-containing gases: Reactive Chlorine Emissions Inventory, J. Geophys. Res., 104, 8333-8346, doi:10.1029/1998JD100079.

King, D. B., J. H. Butler, S. A. Montzka, S. A. Yvon-Lewis, and J. W. Elkins (2000), Implications of methyl bromide supersaturations in the temperate North Atlantic Ocean, J. Geophys. Res., 105, 19,763-19,769, doi:10.1029/2000JD900251. 
King, D. B., J. H. Butler, S. A. Yvon-Lewis, and S. A. Cotton (2002), Predicting oceanic methyl bromide saturation from SST, Geophys. Res. Lett., 29(24), 2199, doi:10.1029/2002GL016091.

Lobert, J. M., J. H. Butler, S. A. Montzka, L. S. Geller, R. C. Myers, and J. W. Elkins (1995), A net sink for atmospheric $\mathrm{CH}_{3} \mathrm{Br}$ in the east Pacific Ocean, Science, 267, 1002-1005, doi:10.1126/science.267.5200.1002.

MacDonald, S., and R. M. Moore (2007), Seasonal and spatial variations in methyl chloride in NW Atlantic waters, J. Geophys. Res., 112, C05028, doi:10.1029/2006JC003812.

Manley, S. L. (1992), Laboratory production of bromoform, methylene bromide, and methyl-iodide by macroalgae and distribution in nearshore Southern California waters, Limnol. Oceanogr., 37, 1652-1659.

Manley, S. L., and M. N. Dastoor (1987), Methyl halide $\left(\mathrm{CH}_{3} \mathrm{X}\right)$ production from the giant kelp, macrocystis, and estimates of global $\mathrm{CH}_{3} \mathrm{X}$ production by kelp, Limnol. Oceanogr., 32, 709-715.

Manley, S. L., and J. L. delaCuesta (1997), Methyl iodide production from marine phytoplankton cultures, Limnol. Oceanogr., 42, 142-147.

Moore, R. M. (2000), The solubility of a suite of low molecular weight organochlorine compounds in seawater and implications for estimating the marine source of methyl chloride to the atmosphere, Chemosphere, 2, 95-99.

Moore, R. M. (2008), A photochemical source of methyl chloride in saline waters, Environ. Sci. Technol., 42, 1933-1937, doi:10.1021/es0719201.

Moore, R. M., and O. C. Zafiriou (1994), Photochemical production of methyl iodide in seawater, J. Geophys. Res., 99, 16,415-16,420, doi:10.1029/94JD00786.

Moore, R. M., W. Groszko, and S. J. Niven (1996), Ocean-atmosphere exchange of methyl chloride: Results from NW Atlantic and Pacific Ocean studies, J. Geophys. Res., 101, 28,529-28,538, doi:10.1029/ 96JC02915.

Ogawa, H., and E. Tanoue (2003), Dissolved organic matter in oceanic waters, J. Oceanogr., 59, 129-147, doi:10.1023/A:1025528919771.

Ooki, A., and Y. Yokouchi (2008), Development of a silicone membrane tube equilibrator for measuring partial pressures of volatile organic compounds in natural water, Environ. Sci. Technol., 42, 5706-5711, doi:10.1021/es800912j.

Richter, U., and D. W. R. Wallace (2004), Production of methyl iodide in the tropical Atlantic Ocean, Geophys. Res. Lett., 31, L23S03, doi:10.1029/2004GL020779.

Scarratt, M. G., and R. M. Moore (1996), Production of methyl chloride and methyl bromide in laboratory cultures of marine phytoplankton, Mar. Chem., 54, 263-272, doi:10.1016/0304-4203(96)00036-9.

Scarratt, M. G., and R. M. Moore (1998), Production of methyl bromide and methyl chloride in laboratory cultures of marine phytoplankton II, Mar. Chem., 59, 311-320, doi:10.1016/S0304-4203(97)00092-3.

Schall, C., K. G. Heumann, and G. O. Kirst (1997), Biogenic volatile organoiodine and organobromine hydro carbons in the Atlantic Ocean from 42 degrees N to 72 degrees S, Fresenius J. Anal. Chem., 359, 298-305, doi:10.1007/s002160050577.

Smythe-Wright, D., S. M. Boswell, P. Breithaupt, R. D. Davidson, C. H. Dimmer, and L. B. E. Diaz (2006), Methyl iodide production in the ocean: Implications for climate change, Global Biogeochem. Cycles, 20, GB3003, doi:10.1029/2005GB002642.

Solomon, S., R. R. Garcia, and A. R. Ravishankara (1994), On the role of iodine in ozone depletion, J. Geophys. Res., 99, 20,491-20,499, doi:10.1029/94JD02028.

Tokarczyk, R., and R. M. Moore (2006), A seasonal study of methyl bromide concentrations in the North Atlantic $\left(35^{\circ}-60^{\circ} \mathrm{N}\right)$, J. Geophys. Res., 111, D08304, doi:10.1029/2005JD006487.

Tokarczyk, R., K. D. Goodwin, and E. S. Saltzman (2003a), Methyl chloride and methyl bromide degradation in the Southern Ocean, Geophys. Res. Lett., 30(15), 1808, doi:10.1029/2003GL017459.

Tokarczyk, R., E. S. Saltzman, R. M. Moore, and S. A. Yvon-Lewis (2003b), Biological degradation of methyl chloride in coastal seawater, Global Biogeochem. Cycles, 17(2), 1057, doi:10.1029/2002GB001949.
Tsuda, A., H. Sugisaki, T. Ishimaru, T. Saino, and T. Sato (1993), Whitenoise like distribution of an oceanic copepod Neocalanus cristatus in the subarctic Pacific, Mar. Ecol. Prog. Ser., 97, 39-46, doi:10.3354/ meps097039.

Wang, L., R. M. Moore, and J. J. Cullen (2009), Methyl iodide in the NW Atlantic: Spatial and seasonal variation, J. Geophys. Res., 114, C07007, doi:10.1029/2007JC004626.

Wanninkhof, R. (1992), Relationship between wind-speed and gasexchange over the ocean, J. Geophys. Res., 97, 7373-7382, doi:10.1029/ 92JC00188.

Welschmeyer, N. A. (1994), Fluorometric analysis of chlorophyll-a in the presence of chlorophyll-b and phaeopigments, Limnol. Oceanogr., 39, 1985-1992, doi:10.4319/1o.1994.39.8.1985.

Wilhelm, E., R. Battino, and R. J. Wilcock (1977), Low-pressure solubility of gases in liquid water, Chem. Rev., 77, 219-262, doi:10.1021/ cr60306a003.

Wong, G. T. F., A. U. Piumsomboon, and W. M. Dunstan (2002), The transformation of iodate to iodide in marine phytoplankton cultures, Mar. Ecol. Prog. Ser., 237, 27-39, doi:10.3354/meps237027.

World Meteorological Organization (WMO) (2007), Scientific Assessment of Ozone Depletion: 2006, Global Res. Monit. Proj. Rep., 50, Geneva.

Yamashita, Y., and E. Tanoue (2008), Production of bio-refractory fluorescent dissolved organic matter in the ocean interior, Nat. Geosci., 1 , 579-582, doi:10.1038/ngeo279.

Yasuda, I. (2003), Hydrographic structure and variability in the KuroshioOyashio transition area, J. Oceanogr., 59, 389-402, doi:10.1023/ A: 1025580313836

Yokouchi, Y., Y. Nojiri, L. A. Barrie, D. Toom-Sauntry, and Y. Fujinuma (2001), Atmospheric methyl iodide: High correlation with surface seawater temperature and its implications on the sea-to-air flux, J. Geophys. Res., 106, 12,661-12,668, doi:10.1029/2001JD900083.

Yokouchi, Y., D. Toon-Sauntry, K. Yazawa, T. Inagaki, and T. Tamaru (2002), Recent decline of methyl bromide in the troposphere, Atmos. Environ., 36, 4985-4989, doi:10.1016/S1352-2310(02)00650-7.

Yokouchi, Y., S. Taguchi, T. Saito, Y. Tohjima, H. Tanimoto, and H. Mukai (2006), High frequency measurements of HFCs at a remote site in East Asia and their implications for Chinese emissions, Geophys. Res. Lett., 33, L21814, doi:10.1029/2006GL026403.

Yokouchi, Y., et al. (2008), Global distribution and seasonal concentration change of methyl iodide in the atmosphere, J. Geophys. Res., 113, D18311, doi:10.1029/2008JD009861.

Yokouchi, Y., T. Saito, H. Mukai, T. Shirai, and S. Sugata (2009), Observational study of halocarbon greenhouse gases to infer changes in emissions in East Asia, interim report, Global Environ. Res. Coord. Syst., Minist. of the Environ. Jpn., Tokyo.

Yoshida, Y., Y. Wang, T. Zeng, and R. Yantosca (2004), A threedimensional global model study of atmospheric methyl chloride budget and distributions, J. Geophys. Res., 109, D24309, doi:10.1029/ 2004JD004951.

Yvon-Lewis, S. A., E. S. Saltzman, and S. A. Montzka (2009), Recent trends in atmospheric methyl bromide: Analysis of post-Montreal Protocol variability, Atmos. Chem. Phys., 9, 5963-5974, doi:10.5194/acp-9-5963-2009.

S. Itoh and A. Tsuda, Atmosphere and Ocean Research Institute, University of Tokyo, Chiba 277-8568, Japan.

S. Kameyama, A. Ooki, and Y. Yokouchi, National Institute for Environmental Studies, 16-2 Onogawa, Tsukubu, Ibaraki 305-8506, Japan. (ooki.atsushi@nies.go.jp)

A. Okubo and S. Takeda, Graduate School of Agricultural and Life Sciences, University of Tokyo, Tokyo 113-8657, Japan.

T. Suga, Department of Geophysics, Graduate School of Science, Tohoku University, Miyagi 980-8578, Japan.

H. Tazoe, College of Humanities and Sciences, Nihon University, Tokyo 156-8550, Japan. 